\title{
Assessing Impacts of Land Use/Land Cover Conversion on Changes in Ecosystem Services Value on the Loess Plateau, China
}

\author{
Wei Jiang *(D), Bojie Fu and Yihe Lü \\ State Key Laboratory of Urban and Regional Ecology, Research Center for Eco-Environmental Sciences, \\ Chinese Academy of Sciences, No.18 Shuangqing Road, Haidian District, Beijing 100085, China; \\ bfu@rcees.ac.cn (B.F.); lyh@rcees.ac.cn (Y.L.) \\ * Correspondence: weijiang@rcees.ac.cn
}

Received: 8 August 2020; Accepted: 27 August 2020; Published: 1 September 2020

\begin{abstract}
The Loess Plateau is not only a critical region that suffers from ecological threats but also a valuable region that provides various fundamental ecosystem services, including provisioning, regulating and cultural services to about $8 \%$ of the Chinese population. The specific natural environment and extensive human activities have led to substantial land use/land cover changes between 1990 and 2015, such as the decrease in cropland with the increase in forests and grasslands due to the implementation of the Grain for Green Program since 2000 and the expansion of built-up areas with economic development and population growth. However, the effects of these changes on ecosystem service values have not yet been considered. In this study, the approach based on a combination of land use/land cover proxies and benefit transfer is applied to assess ecosystem service value changes resulting from land use/land cover changes in the 1990-2000, 2000-2010 and 2010-2015 periods. The results reveal that the total value of ecosystem services has been reduced by $\$ 6.787$ million from 1990 to 2000 and increased by $\$ 4.6$ million from 2000 to 2015 . The elasticity analysis shows that a $1 \%$ area conversion has induced average value changes of $1.03 \%, 0.38 \%$ and $0.05 \%$ in the three periods, respectively. Elasticity is developed as an indicator for locating unusual changes among different regions and identifying specific needs for ecosystem management.
\end{abstract}

Keywords: land use/land cover change; ecosystem service value; benefit transfer; elasticity analysis

\section{Introduction}

Ecosystem services, including provisioning, regulating and cultural services, are necessary for human subsistence, health and well-being [1,2]. The monetary valuation of these services intuitively illustrates the benefits people obtain from ecosystems [3,4], which can be further used to highlight the importance of ecosystems, support relevant policy-making and promote effective ecosystem conservation and management $[5,6]$. Therefore, the assessment of ecosystem service values (ESVs) has attracted much attention in recent years [7].

The approaches proposed for quantifying ESVs generally include two pathways, i.e., primary-data-based and land-use/land-cover (LULC)-proxy-based. The primary-data-based approach refers to ESVs being directly calculated by combined modeling and environmental valuation methods, while the LULC-proxy-based approach means that ESVs are calculated by benefit transfer methods combined with LULC types [8]. In comparison to the expensive and time-consuming primary-data-based approach, the LULC-proxy-based approach is widely used in practice because of its simple operability and effectiveness in areas such as the Ethiopian Highlands [9], China [10], Nigeria [11], and the Ebinur Lake Nature Reserve [12]. 
LULC changes have enormous impacts on ecosystem services. With the accelerated pace of economic development, industrialization and urbanization processes, anthropogenic disturbances of the natural environment are becoming more prevalent, resulting in the increasing vulnerability of ecosystems [13], which may affect ecosystem functions and ecosystem service delivery, such as carbon sequestration [14], air regulation [15], water supply [16], soil retention [17] and flow regulation [18]. LULC changes can be influenced by climate change $[19,20]$ and policy implementation $[21,22]$. The increasing occupation of ecological lands such as forests, grasslands and wetlands through the agricultural transition and urban expansion [23] has led to a considerable loss of pollination [24], biodiversity [25] and wildlife habitats [26]. In contrast, the expansion of ecological lands through ecological restoration can enhance the supply of ecosystem services like carbon sequestration [27]. Different LULC types with specific characteristics play important roles in ecosystem service supply and record the extent of the influences of human activities on nature. Appropriate LULC management that aims to enhance ecosystem service supply can make necessary contributions to regional sustainable development.

The Chinese Loess Plateau (LP) suffers from drastic human activities (e.g., large-scale deforestation and long-term cultivation) and severe environmental conditions (e.g., highly erodible loess soil, unevenly distributed precipitation and fragmented landforms); thus, it has become one of the most vulnerable and eroded regions in the world. Soil erosion is the major ecological threat and has seriously reduced agricultural productivity, depleted water resources and degraded ecosystems. In order to alleviate soil erosion and improve ecosystem services, the Chinese government initiated the Grain for Green Program (GFGP) in 1999, which requires converting steep-slope cropland to forests or grasslands [28]. The effects of ecological restoration on ecosystem services after twenty years of the implementation of the GFGP have drawn widespread scientific and public attention. Many studies report the spatial patterns, temporal variations and trade-offs of different ecosystem services at the regional [29], subregional [30], watershed [31] and local scales [32]. However, few studies consider the impacts of LULC changes on ESVs in this critical region. Hence, this study attempts to make an effort by (1) identifying LULC changes from 1990 to 2015, (2) illustrating ESV changes resulting from LULC changes and (3) analyzing the elasticity of ESV changes in response to LULC changes.

\section{Materials and Methods}

\subsection{Study Area}

The LP $\left(33^{\circ} 43^{\prime}-41^{\circ} 16^{\prime} \mathrm{N}, 100^{\circ} 54^{\prime}-114^{\circ} 33^{\prime} \mathrm{E}\right)$ is located in north-central China, with an area of about $620,000 \mathrm{~km}^{2}$. It is more than $1000 \mathrm{~km}$ long from east to west and $750 \mathrm{~km}$ wide from north to south; the elevation ranges from 88 to $5204 \mathrm{~m}$ (Figure 1). The LP belongs to the temperate continental climate zone; its annual temperature ranges from 4 to $14^{\circ} \mathrm{C}$, and its annual precipitation, from 200 to $750 \mathrm{~mm}$. The unevenly distributed precipitation ( $60-70 \%$ of rainfall occurs between June and September) and the most concentrated and largest distribution of loess soil in the world have shaped a very complicated topography, including basins, sub plateaus, hills and gullies. Around $8.5 \%$ of the Chinese population lives in ca. $6.6 \%$ of China's territory; the population density reaches 168 people $/ \mathrm{km}^{2}$ [33]. The LP covers 44 administrative cities in seven provinces, including the Inner Mongolia Autonomous Region and Qinghai, Gansu, Ningxia, Shaanxi, Shanxi and Henan provinces.

The LP was covered by widespread forest steppes and grasslands in the Holocene [34]. Rapid population growth and increased human activities, especially over-reclamation and overgrazing, have led to significant vegetation degradation and accelerated soil erosion [35]. The average annual erosion amount reaches ca. 7500 tons $/ \mathrm{km}^{2}$, with the highest amount at ca. 25,000 tons $/ \mathrm{km}^{2}$, which forms the major source of sediment flowing into the Yellow River [36]. Water shortages are another critical concern on the LP. The water utilization ratio reaches $70 \%$, significantly exceeding the international water utilization threshold of $40 \%$ [37]. The implementation of the GFGP has considerably improved 
this situation [38], but the GFGP per se, together with economic development and urbanization progress, has greatly altered the LULC pattern on the LP.

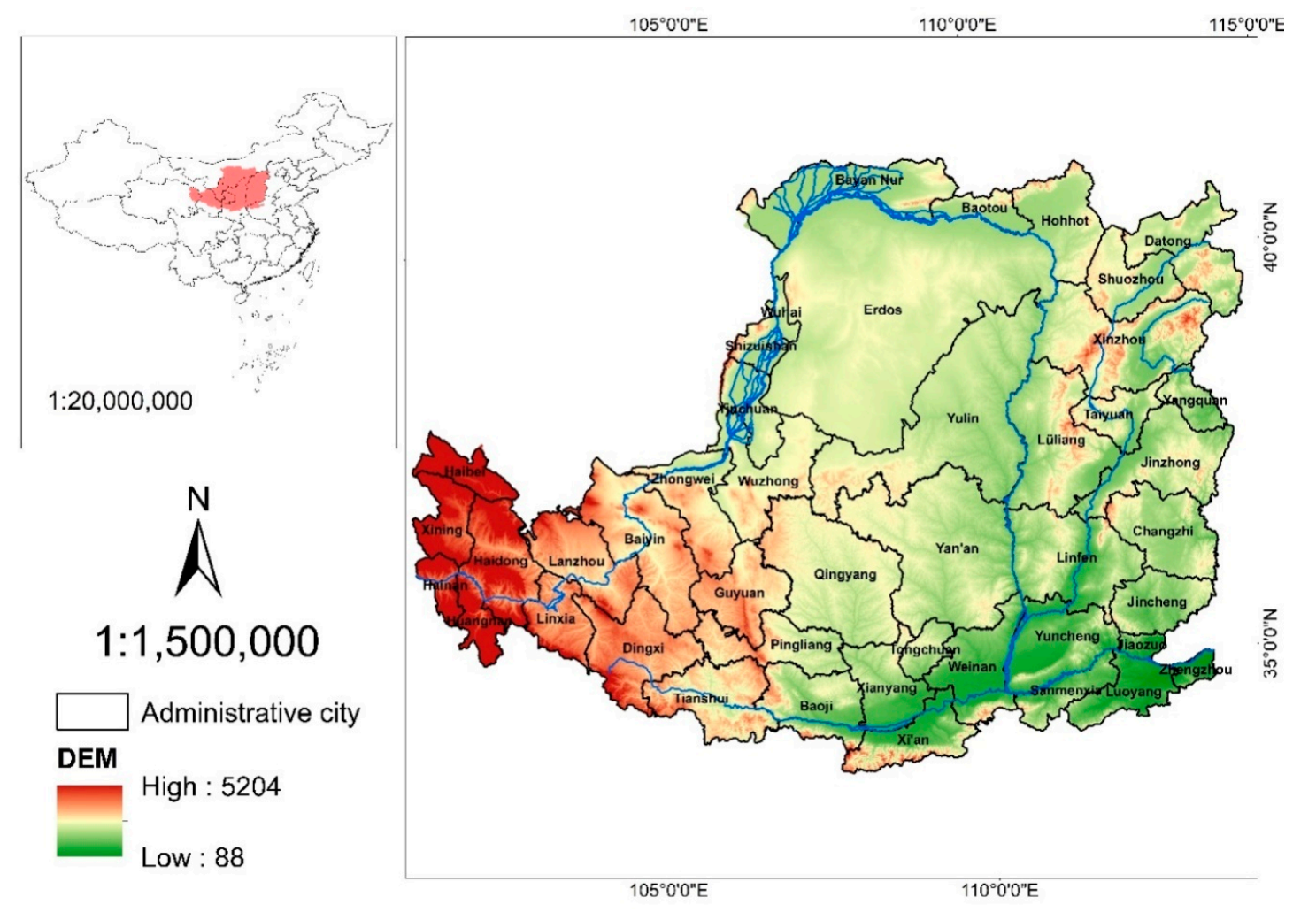

Figure 1. The geography of the Loess Plateau.

\subsection{Identifying $L U L C$}

The $30 \times 30 \mathrm{~m}$ raster of LULC data from 1990, 2000, 2010 and 2015 were obtained from the ChinaCover dataset, which includes six primary classes (forestland, grassland, cropland, wetland, built-up land and other land) and 40 secondary classes. This dataset has been validated by over 100,000 ground test samples and 13 rounds of large-scale cross-checks; the average accuracy for 2010 reaches $94 \%$ in the primary classes and $86 \%$ in the secondary classes [39]. In order to be in accordance with the LULC classification used by [40], the ChinaCover data was redefined (Table 1).

Table 1. Reclassification of land use/land cover (LULC).

\begin{tabular}{cc}
\hline LULC [40] & China Cover [39] \\
\hline Dry farmland & Dry farmland \\
\hline Paddy field & Paddy field \\
\hline Coniferous forest & Evergreen needleleaf forest \\
\cline { 2 - 2 } & Deciduous needleleaf forest \\
\hline Mixed forest & Broadleaf and needleleaf mixed forest \\
\hline \multirow{2}{*}{ Broad-leaved forest } & Evergreen broadleaf forest \\
\cline { 2 - 2 } & Deciduous broadleaf forest \\
\cline { 2 - 2 } Bush & Evergreen broadleaf shrubland \\
\cline { 2 - 2 } & Deciduous broadleaf shrubland \\
\cline { 2 - 2 } & Evergreen needleleaf shrubland \\
\cline { 2 - 2 } & Sparse forest \\
\hline
\end{tabular}


Table 1. Cont.

\begin{tabular}{|c|c|}
\hline LULC [40] & China Cover [39] \\
\hline \multirow{4}{*}{ Bush } & Tree orchard \\
\hline & Shrub orchard \\
\hline & Tree garden \\
\hline & Shrub garden \\
\hline \multirow{2}{*}{ Prairie } & Temperate steppe \\
\hline & Alpine steppe \\
\hline \multirow{3}{*}{ Shrub grass } & Tussock \\
\hline & Sparse grassland \\
\hline & Lawn \\
\hline \multirow{2}{*}{ Meadow } & Temperate meadow \\
\hline & Alpine meadow \\
\hline \multirow{3}{*}{ Wetland } & Tree wetland \\
\hline & Shrub wetland \\
\hline & Herbaceous wetland \\
\hline \multirow{4}{*}{ River and lake } & Lake \\
\hline & Reservoir/pond \\
\hline & River \\
\hline & Canal/channel \\
\hline Glacier and snow & Permanent ice/snow \\
\hline \multirow{3}{*}{ Desert } & Moss/lichen \\
\hline & Gobi \\
\hline & Desert \\
\hline \multirow{3}{*}{ Bare land } & Bare rock \\
\hline & Bare soil \\
\hline & Salina \\
\hline \multirow{3}{*}{ Built-up area } & Settlement \\
\hline & Transportation land \\
\hline & Mining field \\
\hline
\end{tabular}

\subsection{Calculating ESVs}

The benefit transfer method was used to estimate the economic values of ecosystem services by transferring available information from one or more already-completed studies to other sites where primary information was lacking [41,42]. This method was applied to estimate the value of 17 ecosystem services of 16 LULC types at a global scale [3]. These results were adjusted for nine ecosystem services of the six main LULC types in China based on questionnaires from Chinese ecological specialists [43]. The equivalent coefficients method was developed for further improving the unit value of 11 ecosystem services of 14 LULC types [40]. Thus, these unit values were more reliable for calculating ESVs in China.

The equivalent coefficients method consists of a standard equivalent factor and an equivalent coefficients table. The standard equivalent factor is based on the price of natural grain output from 1 ha of farmland in China, which was estimated to be 503.2 US dollars per ha (\$/ha) at the price level in 2010. The equivalent coefficients table is the valuation weight for each ecosystem service provided by each LULC type. Thus, the unit value of a given ecosystem service provided by a given LULC type is equal to the product of the standard equivalent factor and the corresponding equivalent coefficients [40]. The unit value of a built-up area was assigned to be 0 because it was not considered (Table 2). 
Table 2. Unit values of ecosystem services (US dollars per ha (\$/ha)).

\begin{tabular}{|c|c|c|c|c|c|c|c|c|c|c|c|}
\hline \multirow[b]{2}{*}{ LULC } & \multicolumn{3}{|c|}{ Provisioning Services } & \multicolumn{6}{|c|}{ Regulating Services } & \multirow[b]{2}{*}{ Habitat Services } & \multirow[b]{2}{*}{ Cultural Service } \\
\hline & Food & Materials & Water & $\begin{array}{l}\text { Air Quality } \\
\text { Regulation }\end{array}$ & $\begin{array}{c}\text { Climate } \\
\text { Regulation }\end{array}$ & $\begin{array}{c}\text { Waste } \\
\text { Treatment }\end{array}$ & $\begin{array}{l}\text { Water Flow } \\
\text { Regulation }\end{array}$ & $\begin{array}{c}\text { Erosion } \\
\text { Prevention }\end{array}$ & $\begin{array}{l}\text { Soil Fertility } \\
\text { Maintenance }\end{array}$ & & \\
\hline Dry farmland & 427.72 & 201.28 & 10.06 & 337.14 & 181.15 & 50.32 & 135.86 & 518.3 & 60.38 & 65.42 & 30.19 \\
\hline Paddy field & 684.35 & 45.29 & -1323.42 & 558.55 & 286.82 & 85.54 & 1368.7 & 5.03 & 95.61 & 105.67 & 45.29 \\
\hline Coniferous forest & 110.7 & 261.66 & 135.86 & 855.44 & 2551.22 & 749.77 & 1680.69 & 1036.59 & 80.51 & 946.02 & 412.62 \\
\hline Mixed forest & 155.99 & 357.27 & 186.18 & 1182.52 & 3537.5 & 1001.37 & 1766.23 & 1439.15 & 110.7 & 1308.32 & 573.65 \\
\hline Broad-leaved forest & 145.93 & 332.11 & 171.09 & 1091.94 & 3270.8 & 971.18 & 2385.17 & 1333.48 & 100.64 & 1212.71 & 533.39 \\
\hline Bush & 95.61 & 216.38 & 110.7 & 709.51 & 2128.54 & 644.1 & 1685.72 & 865.5 & 65.42 & 790.02 & 347.21 \\
\hline Prairie & 50.32 & 70.45 & 40.26 & 256.63 & 674.29 & 221.41 & 493.14 & 311.98 & 25.16 & 281.79 & 125.8 \\
\hline Shrub grass & 191.22 & 281.79 & 155.99 & 991.3 & 2621.67 & 865.5 & 1922.22 & 1207.68 & 90.58 & 1096.98 & 483.07 \\
\hline Meadow & 110.7 & 166.06 & 90.58 & 573.65 & 1519.66 & 503.2 & 1112.07 & 699.45 & 55.35 & 639.06 & 281.79 \\
\hline Wetland & 256.63 & 251.6 & 1303.29 & 956.08 & 1811.52 & 1811.52 & $12,192.54$ & 1162.39 & 90.58 & 3960.18 & 2380.14 \\
\hline River and lake & 402.56 & 115.74 & 4171.53 & 387.46 & 1152.33 & 2792.76 & $51,447.17$ & 467.98 & 35.22 & 1283.16 & 951.05 \\
\hline Glacier and snow & 0 & 0 & 1086.91 & 90.58 & 271.73 & 80.51 & 3587.82 & 0 & 0 & 5.03 & 45.29 \\
\hline Desert & 5.03 & 15.1 & 10.06 & 55.35 & 50.32 & 155.99 & 105.67 & 65.42 & 5.03 & 60.38 & 25.16 \\
\hline Bare land & 0 & 0 & 0 & 10.06 & 0 & 50.32 & 15.1 & 10.06 & 0 & 10.06 & 5.03 \\
\hline Built-up area & 0 & 0 & 0 & 0 & 0 & 0 & 0 & 0 & 0 & 0 & 0 \\
\hline
\end{tabular}


The total ESV is calculated by

$$
\begin{gathered}
V_{i}=\sum_{k=1}^{11} U V_{i k} \\
E S V=\sum_{i=1}^{15} V_{i} \times A_{i}
\end{gathered}
$$

where $V_{i}$ is the total value of LULC type $i$, which equals the sum of the unit value $\left(U V_{i k}\right)$ of ecosystem services for 11 categories that can be obtained from Table 2. $A_{i}$ is the area of LULC type $i$, which is automatically calculated by ArcMap 10.6. The total ESV is the sum of the products of $V_{i}$ and $A_{i}$ for the 15 LULC types.

\subsection{Analyzing Elasticity of ESV Changes in Response to LULC Changes}

By analogy to the concept of elasticity in economics, Jiang et al. [44] proposed an indicator of elasticity for reflecting the response of ESV changes to LULC changes. It measures the percentage change in ESVs as a result of the percentage change in LULC.

For a given LULC type $i$, its elasticity is calculated by

$$
E_{i}=\left|\frac{\Delta E S V_{i} / E S V_{\text {start }}}{\Delta A_{i} / A_{\text {total }}}\right|
$$

where $E_{i}$ is the elasticity of LULC type $i, \triangle A_{i}$ is the converted area of LULC type $i$ in a given period, $\triangle E S V_{i}$ is the $E S V$ change resulting from LULC conversion, $A_{\text {total }}$ is the total area of a given region and $E S V_{\text {start }}$ is the total $E S V$ at the beginning of the given period.

For a given region, like a municipality or the whole study area, the elasticity is calculated by

$$
E=\left|\frac{\Delta E S V / E S V_{\text {start }}}{\Delta A / A_{\text {total }}}\right|
$$

where $E$ is the elasticity of the given region, $\triangle A$ is the total area of the converted LULC types in a given period, $\triangle E S V$ is the total $E S V$ change in the given region during the given period, $A_{\text {total }}$ is the total area of the region and $E S V_{\text {start }}$ is the total $E S V$ in the region at the beginning of the period. The larger the elasticity of a LULC type is, the greater the impact this LULC type has on the total ESV change.

The elasticity was explained as follows: a 1\% area conversion results in the E\% of ESV changes in the given region in the given period. It is reasonable that the elasticity would be large when a small area conversion resulted in a great ESV change. The elasticity could be divided into three levels, $0<\mathrm{E}<0.5,0.5 \leq \mathrm{E}<1$ and $\mathrm{E} \geq 1$, indicating that the responses of ESV changes to LULC changes were inelastic, elastic and very elastic, respectively.

\section{Results}

\subsection{LULC Conversion between 1990 and 2015}

In 1990, the LP was predominantly covered by grasslands, including prairies, shrub grass and meadows (ca. 23 million ha, taking up 37\% of the region); dry farmland (ca. 19 million ha, taking up $31 \%$ ); and forestlands, including coniferous forests, broad-leaved forests, mixed forests and bush (ca. 13 million ha, taking up 21\%). Grasslands were mainly located in the center and southwest of the LP; dry farmland was distributed in the north, east and south; and most of the forestlands were found in the east (Figure 2). Bare land accounted for $4 \%$ of the LP; built-up areas and deserts respectively occupied ca. $3 \%$; wetlands, rivers and lakes as well as glaciers and snow together accounted for less than $1 \%$ (Table 3 ). 
Table 3. The area of land use/land cover types in 1990, 2000, 2010 and 2015.

\begin{tabular}{|c|c|c|c|c|c|c|c|c|}
\hline \multirow{2}{*}{$\begin{array}{c}\text { Year } \\
\text { LULC }\end{array}$} & \multicolumn{2}{|c|}{1990} & \multicolumn{2}{|c|}{2000} & \multicolumn{2}{|c|}{2010} & \multicolumn{2}{|c|}{2015} \\
\hline & Area (ha) & Percent & Area (ha) & Percent & Area (ha) & Percent & Area (ha) & Percent \\
\hline Dry farmland & $19,472,293$ & $31.25 \%$ & $19,506,873$ & $31.30 \%$ & $18,151,785$ & $29.13 \%$ & $17,947,533$ & $28.80 \%$ \\
\hline Paddy field & 174,004 & $0.28 \%$ & 182,162 & $0.29 \%$ & 184,742 & $0.30 \%$ & 179,297 & $0.29 \%$ \\
\hline Coniferous forest & $1,047,766$ & $1.68 \%$ & $1,047,277$ & $1.68 \%$ & $1,048,730$ & $1.68 \%$ & $1,048,223$ & $1.68 \%$ \\
\hline Mixed forest & 375,272 & $0.60 \%$ & 373,266 & $0.60 \%$ & 374,515 & $0.60 \%$ & 374,076 & $0.60 \%$ \\
\hline Broad-leaved forest & $3,461,729$ & $5.56 \%$ & $3,470,623$ & $5.57 \%$ & $3,498,933$ & $5.62 \%$ & $3,499,165$ & $5.62 \%$ \\
\hline Bush & $8,460,955$ & $13.58 \%$ & $8,505,503$ & $13.65 \%$ & $8,741,112$ & $14.03 \%$ & $8,742,781$ & $14.03 \%$ \\
\hline Prairie & $12,116,088$ & $19.44 \%$ & $12,117,713$ & $19.45 \%$ & $12,589,808$ & $20.20 \%$ & $12,590,323$ & $20.20 \%$ \\
\hline Shrub grass & $10,312,821$ & $16.55 \%$ & $10,267,643$ & $16.48 \%$ & $10,473,953$ & $16.81 \%$ & $10,446,975$ & $16.77 \%$ \\
\hline Meadow & 777,767 & $1.25 \%$ & 779,398 & $1.25 \%$ & 795,663 & $1.28 \%$ & 796,513 & $1.28 \%$ \\
\hline Wetland & 98,295 & $0.16 \%$ & 93,982 & $0.15 \%$ & 99,295 & $0.16 \%$ & 85,520 & $0.14 \%$ \\
\hline River and lake & 439,548 & $0.71 \%$ & 333,719 & $0.54 \%$ & 357,665 & $0.57 \%$ & 377,282 & $0.61 \%$ \\
\hline Glacier and snow & 10,679 & $0.02 \%$ & 5358 & $0.01 \%$ & 8248 & $0.01 \%$ & 7793 & $0.01 \%$ \\
\hline Desert & $1,601,789$ & $2.57 \%$ & $1,572,011$ & $2.52 \%$ & $1,546,439$ & $2.48 \%$ & $1,507,441$ & $2.42 \%$ \\
\hline Bare land & $2,363,022$ & $3.79 \%$ & $2,268,582$ & $3.64 \%$ & $2,233,455$ & $3.58 \%$ & $2,252,058$ & $3.61 \%$ \\
\hline Built-up area & $1,602,038$ & $2.57 \%$ & $1,789,957$ & $2.87 \%$ & $2,209,725$ & $3.55 \%$ & $2,459,089$ & $3.95 \%$ \\
\hline Total & $62,314,068$ & $100.00 \%$ & $62,314,068$ & $100.00 \%$ & $62,314,068$ & $100.00 \%$ & $62,314,068$ & $100.00 \%$ \\
\hline
\end{tabular}




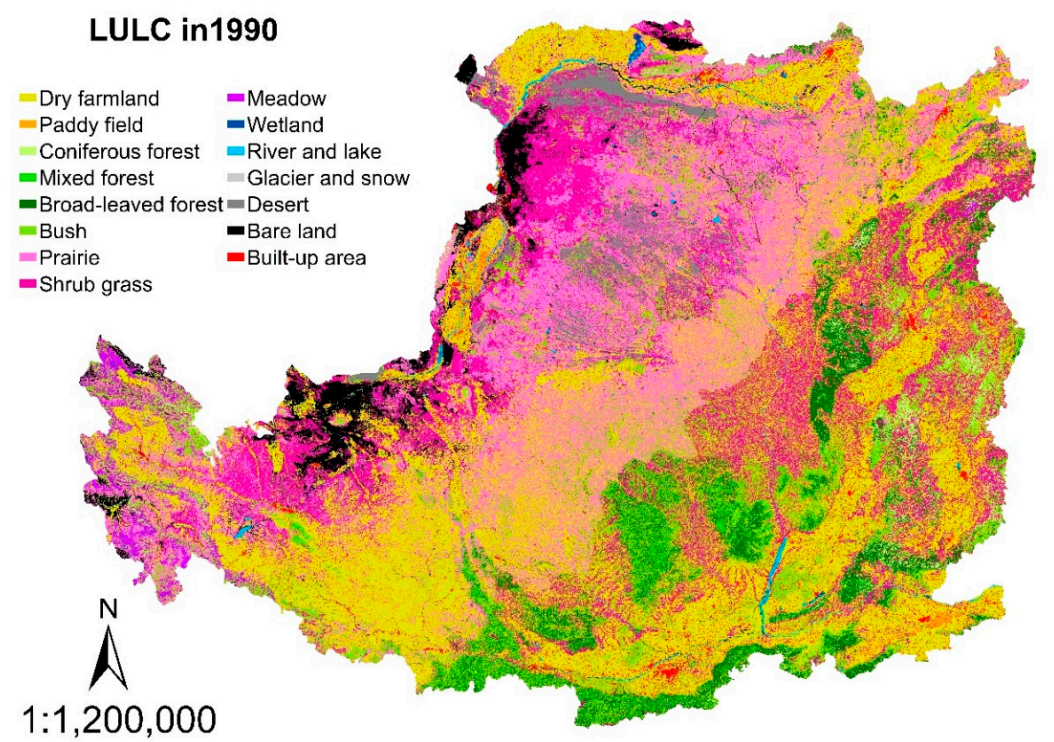

Figure 2. The land use/land cover in 1990.

The trend in LULC changes on the LP over 25 years was marked by a substantial reduction in dry farmland (from $31.25 \%$ in 1990 to $28.80 \%$ in 2015); the enlargement of the bush (from $13.58 \%$ in 1990 to $14.03 \%$ in 2015); the increase in prairies (from $19.44 \%$ in 1990 to $20.20 \%$ in 2015 ) and shrub grass (from $16.55 \%$ in 1990 to $16.77 \%$ in 2015); the decrease in wetlands (from $0.16 \%$ in 1990 to $0.14 \%$ in 2015), rivers and lakes (from $0.71 \%$ in 1990 to $0.61 \%$ in 2015); the shrinkage of deserts (from $2.57 \%$ in 1990 to $2.42 \%$ in 2015) and bare land (from 3.79\% in 1990 to $3.61 \%$ in 2015); and the considerable expansion of built-up areas (from $2.57 \%$ in 1990 to $3.95 \%$ in 2015) (Table 3). The spatial distribution and transition matrices of LULC conversion in the 1990-2000, 2000-2010 and 2010-2015 periods are illustrated in Appendix A, Figures A1-A3 and Tables A1-A3, respectively.

\subsection{ESV Changes between 1990 and 2015}

From 1990 to 2000, the total ESV on the LP experienced a decrease of $\$ 6.787$ million. Since the implementation of the GFGP in 2000, it began to rise steadily, reaching $\$ 324.745$ million in 2010 and $\$ 324.924$ million in 2015, but did not exceed the total ESV in 1990. The value of regulating services accounted for the largest percentage (ca. \$250 million). Its changing trend was the same as that of the total ESV, decreasing in the first period and increasing in the last two periods. The value of provisioning services was reduced gradually from $\$ 29.982$ million in 1990 to $\$ 28.994$ million in 2015 . The values of habitat and cultural services declined from 1990 to 2000; peaked in 2010 at $\$ 30.352$ million and $\$ 13.6$ million, respectively; and were slightly diminished in 2015 but still exceeded the values in 1990 (Figure 3).

At the municipal scale, in 1990, Erdos provided the greatest value of provisioning services (more than \$2 million), while Wuhai and Hainan provided the smallest ones (less than \$100 million; Figure 4a). Erdos also had the largest value of regulating services (more than $\$ 30$ million), while Wuhai and Zhengzhou had the smallest ones (less than $\$ 1$ million; Figure $4 \mathrm{~b}$ ). The greatest values of habitat services were found in Erdos and Yan'an (more than \$2 million), while the smallest ones were found in Zhengzhou and Wuhai (less than $\$ 100$ million; Figure 4c). The largest values of cultural services were also provided by Erdos and Yan'an (more than $\$ 1$ million), but the smallest ones were found in six cities (less than $\$ 100$ million; Figure $4 d$ ). In total, the ESVs of Erdos and Yan'an were greater than $\$ 20$ million, while the ESVs of Wuhai and Zhengzhou were smaller than $\$ 1$ million (Figure 4e). On average, the highest unit ESVs (more than $\$ 7000 /$ ha) were found in Jiaozuo, Lüliang, Yuncheng, Baoji and Yangquan, while the lowest ones (less than $\$ 4000 /$ ha) were provided by Dingxi, Guyuan, Baiyin, Hainan, Hohhot, Shuozhou and Qingyang (Figure 4f). 


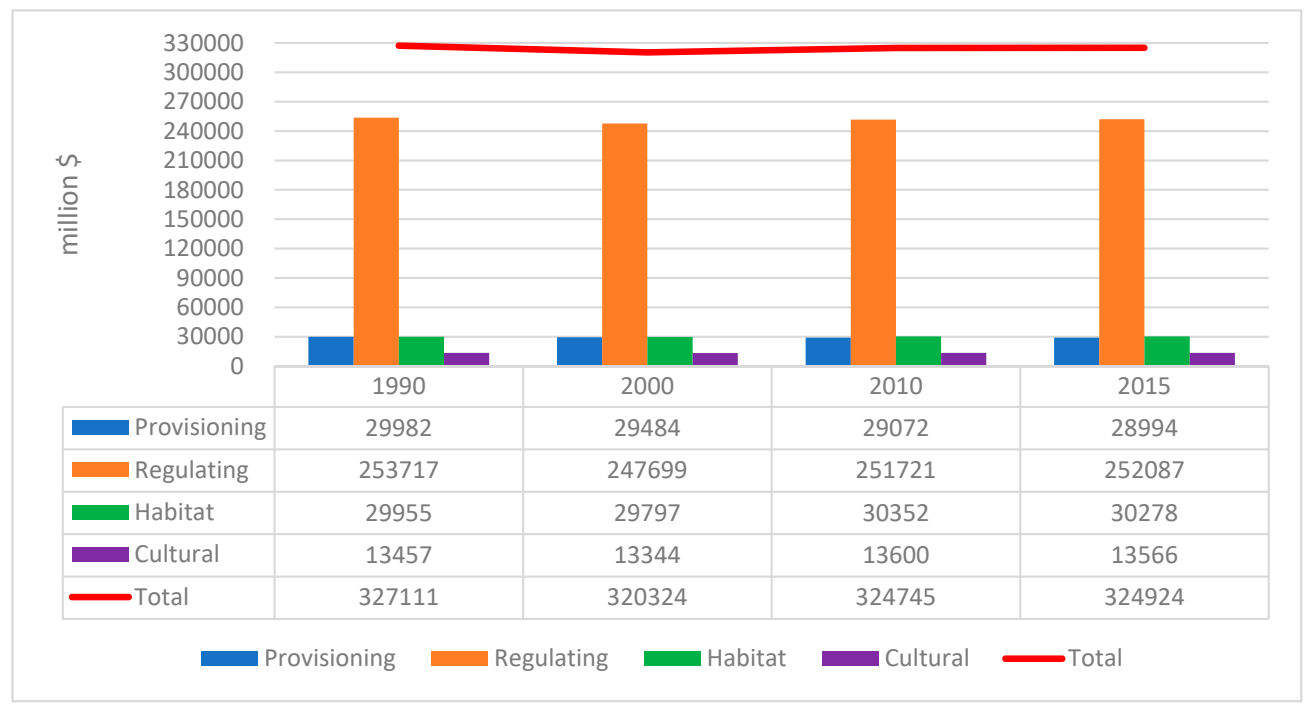

Figure 3. The change in ecosystem service values (ESVs) from 1990 to 2015.
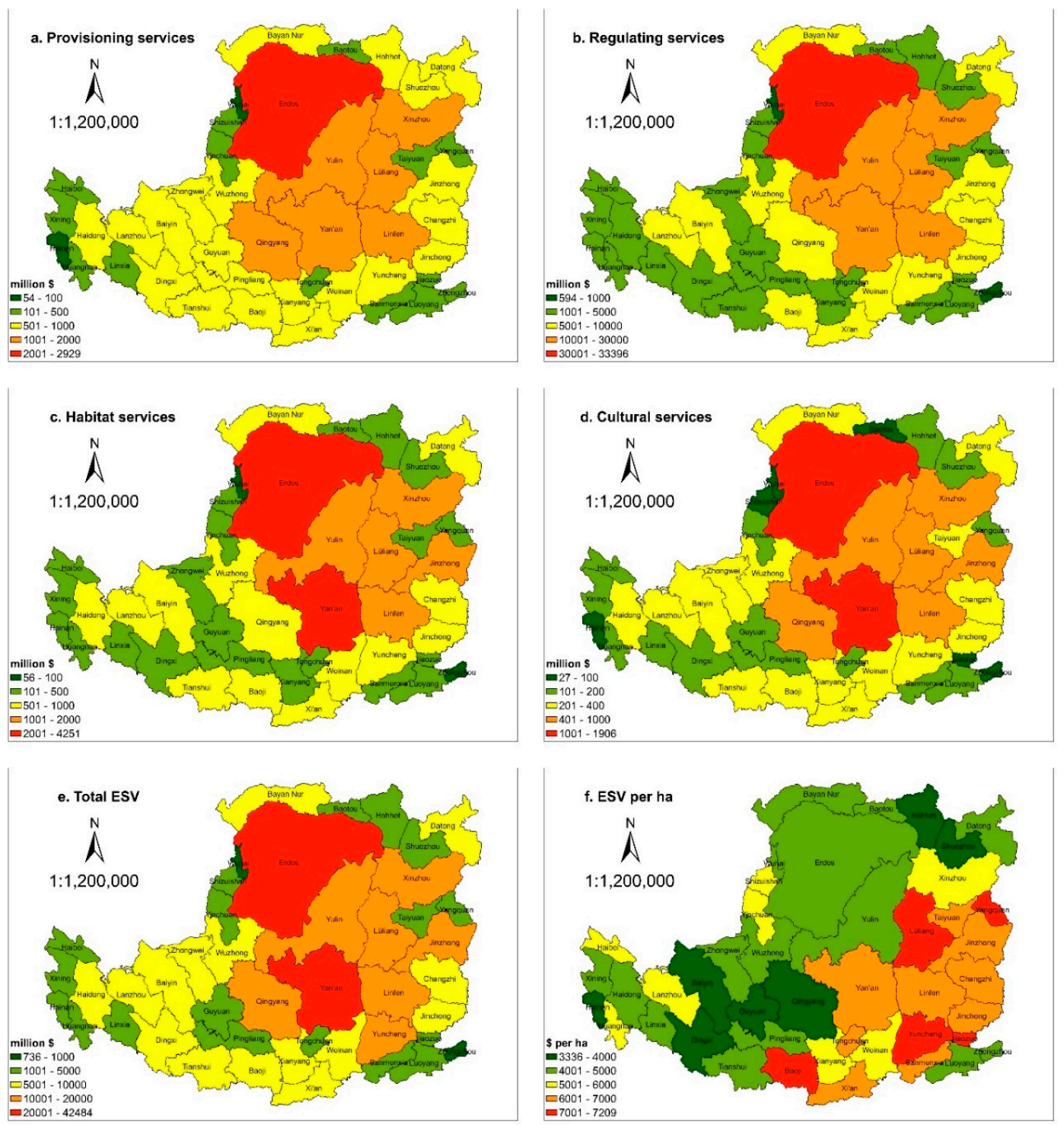

Figure 4. The distribution of ecosystem service values at a municipal scale in 1990. 
During the first decade, although the total ESV experienced a decline, eight cities still had an increase in ESVs, among which Luoyang had the largest gain (ca. \$175 million). The greatest ESV loss occurred in Erdos ( $\$ 1.365$ million; Figure 5a). Huangnan had the largest gain in its unit ESV (\$11,290/ha), and Yuncheng had the largest loss (\$23,031/ha; Figure 5b). Between 2000 and 2010, in the context of the obvious recovery of the total ESV, nine cities still experienced a decrease, among which Yuncheng had the greatest loss (\$191 million). The greatest increase appeared in Yan'an (\$976 million; Figure 5c). However, the largest decrease in the unit ESV was found in Linxia ( $\$ 8.619$ million/ha), and the largest increase was found in Huangnan (\$13,000/ha; Figure 5d). From 2010 to 2015, almost half of the cities on the LP experienced an increase in ESVs, while the other half experienced a decrease. The greatest increases (more than \$100 million) were found in Wuhai, Yan'an, Jiaozuo, Luoyang and Sanmenxia, while the greatest decreases (more than $\$ 100$ million) were found in Weinan and Shizuishan (Figure 5e). The largest gains in the unit ESV (more than $\$ 10,000 /$ ha) occurred in Wuhai, Hainan, Jiaozuo and Linxia, among which Linxia had the greatest one (\$42,296/ha), while the largest losses in the unit ESV (more than \$5000/ha) occured in Shizuishan, Weinan, Taiyuan, Yangquan and Huangnan, among which Shizuishan had the greatest one $(\$ 13,076 /$ ha; Figure $5 f)$. The changes in provisioning service values, regulating service values, habitat service values and cultural service values at a municipal scale during the three periods are illustrated in Appendix A, Figures A4-A6, respectively.
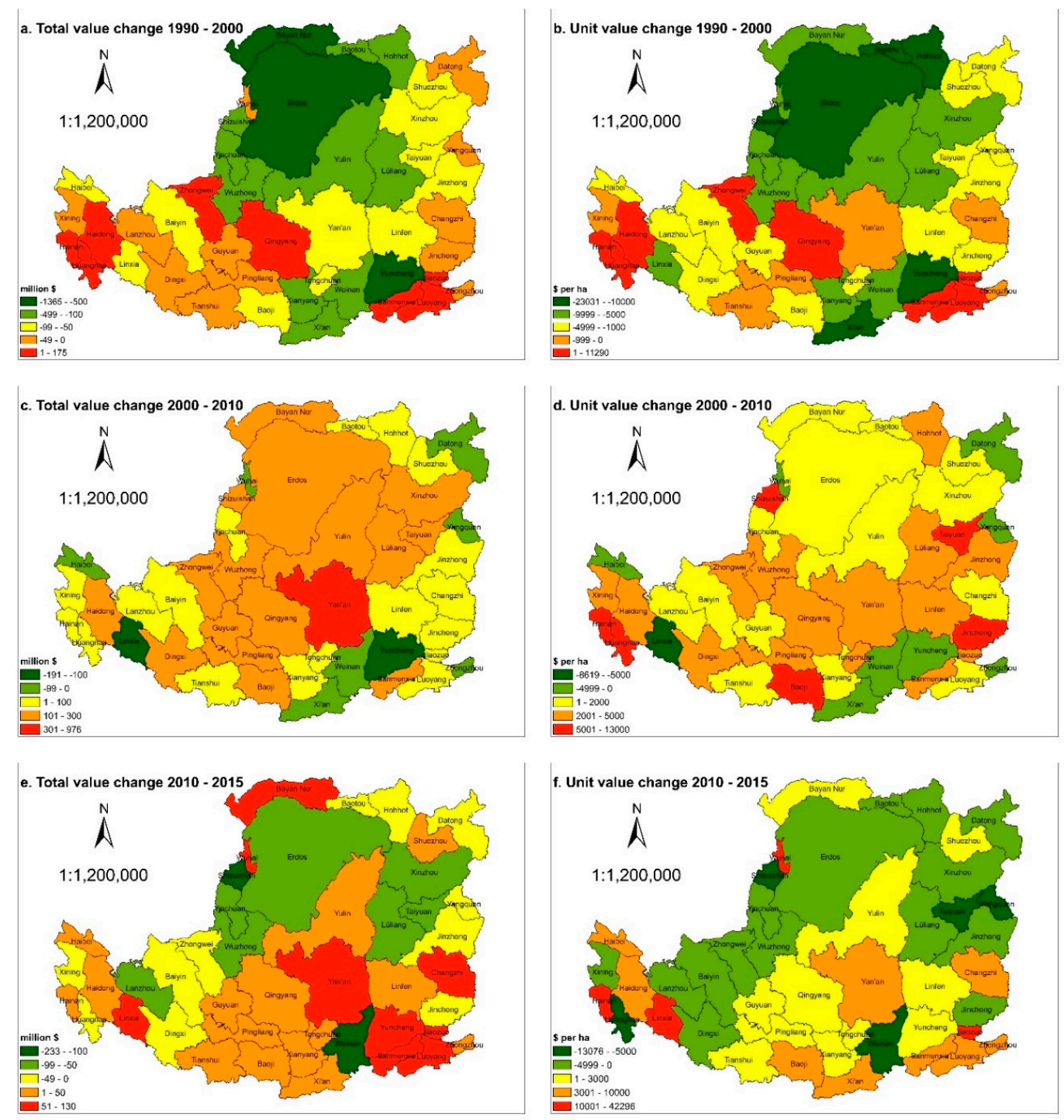

Figure 5. The changes in the total and unit ecosystem service values from 1990 to 2015. 


\subsection{Elasticity Analysis}

The elasticity of each LULC type except for built-up areas was calculated for the three periods (Table 4). Since built-up areas were not assigned any value, they were not considered. The elasticities of all LULC types were very close but not identical in the three periods because the total ESVs at the beginning of these periods were not the same. Taking the elasticities in the 2000-2010 period as an example, the elasticity values of coniferous forests, mixed forests, broad-leaved forests, bush, shrub grass, meadows, wetlands, rivers/lakes and glaciers/snow were larger than 1, indicating that the ESV changes resulting from area conversion of these LULC types was very elastic. Since rivers and lakes provided larger ESVs than other LULC types, especially the considerably larger values of water provisioning and water flow regulation, their elasticity was the largest, equal to 12.3 , meaning that a $1 \%$ area conversion of rivers/lakes led to a $12.3 \%$ ESV change.

Table 4. Elasticity of LULC types in the three periods.

\begin{tabular}{|c|c|c|c|}
\hline LULC Period & 1990-2000 & $2000-2010$ & 2010-2015 \\
\hline Dry farmland & 0.38 & 0.39 & 0.39 \\
\hline Paddy field & 0.37 & 0.38 & 0.38 \\
\hline Coniferous forest & 1.68 & 1.72 & 1.69 \\
\hline Mixed forest & 2.21 & 2.26 & 2.23 \\
\hline Broad-leaved forest & 2.2 & 2.25 & 2.22 \\
\hline Bush & 1.46 & 1.49 & 1.47 \\
\hline Prairie & 0.49 & 0.5 & 0.49 \\
\hline Shrub grass & 1.89 & 1.93 & 1.9 \\
\hline Meadow & 1.1 & 1.12 & 1.1 \\
\hline Wetland & 4.99 & 5.09 & 5.02 \\
\hline River and lake & 12.04 & 12.3 & 12.13 \\
\hline Glacier and snow & 0.98 & 1.01 & 0.99 \\
\hline Desert & 0.11 & 0.11 & 0.11 \\
\hline Bare land & 0.02 & 0.02 & 0.02 \\
\hline
\end{tabular}

In summary, the converted area during the three periods accounted for $2.01 \%, 3.61 \%$ and $1.32 \%$ of the total area on the LP, respectively. The ESVs decreased by $\$ 6.787$ million in the first period and then increased by $\$ 4.421$ million and $\$ 179$ million in the last two periods, respectively, accounting for $2.07 \%$, $13.8 \%$ and $0.06 \%$ of the ESVs at the beginning of the corresponding periods (Table 5). At a regional level, the elasticity in the three periods was $1.03,0.38$ and 0.05 , respectively, meaning that a $1 \%$ LULC conversion resulted in $1.03 \%, 0.38 \%$ and $0.05 \%$ ESV changes. The elasticity indicated that the response of the ESV changes to LULC conversion was very elastic from 1990 to 2000 but inelastic in the other two periods.

Table 5. Land use/land cover conversion and ecosystem service changes during the three periods.

\begin{tabular}{ccccccc}
\hline Period & Total Area (ha) & Converted Area (ha) & Percent & $\begin{array}{c}\text { ESV Start } \\
\text { (millions of \$) }\end{array}$ & $\begin{array}{c}\text { ESV Change } \\
\text { (millions of \$) }\end{array}$ & Percent \\
\hline $1990-2000$ & $62,314,068$ & $1,250,860$ & $2.01 \%$ & 327,111 & -6787 & $2.07 \%$ \\
\hline $2000-2010$ & $62,314,068$ & $2,250,331$ & $3.61 \%$ & 320,324 & 4421 & $1.38 \%$ \\
\hline $2010-2015$ & $62,314,068$ & 823,434 & $1.32 \%$ & 324,745 & 179 & $0.06 \%$ \\
\hline
\end{tabular}


At a municipal level, cities had different elasticities in the three periods. Between 1990 and 2000, 19 cities were very elastic, among which Baotou had the largest elasticity at 3.78 (Figure 6a). From 2000 to 2010, only seven cities had an elasticity over 1, among which Huangnan had the largest one at 2.44 (Figure 6b). During the last period, the elasticities in 11 cities were larger than 1, among which the elasticity in Linxia was the greatest one, even reaching 9.18 (Figure 6c). The elasticity of a city varied obviously in different periods. This was determined by the conversion of LULC types, their areas and the ESV changes resulting from the conversion. In the three periods, the elasticity of three cities on the LP were always larger than 1, i.e., Wuhai, Shizuishan and Linxia (Figure 6).
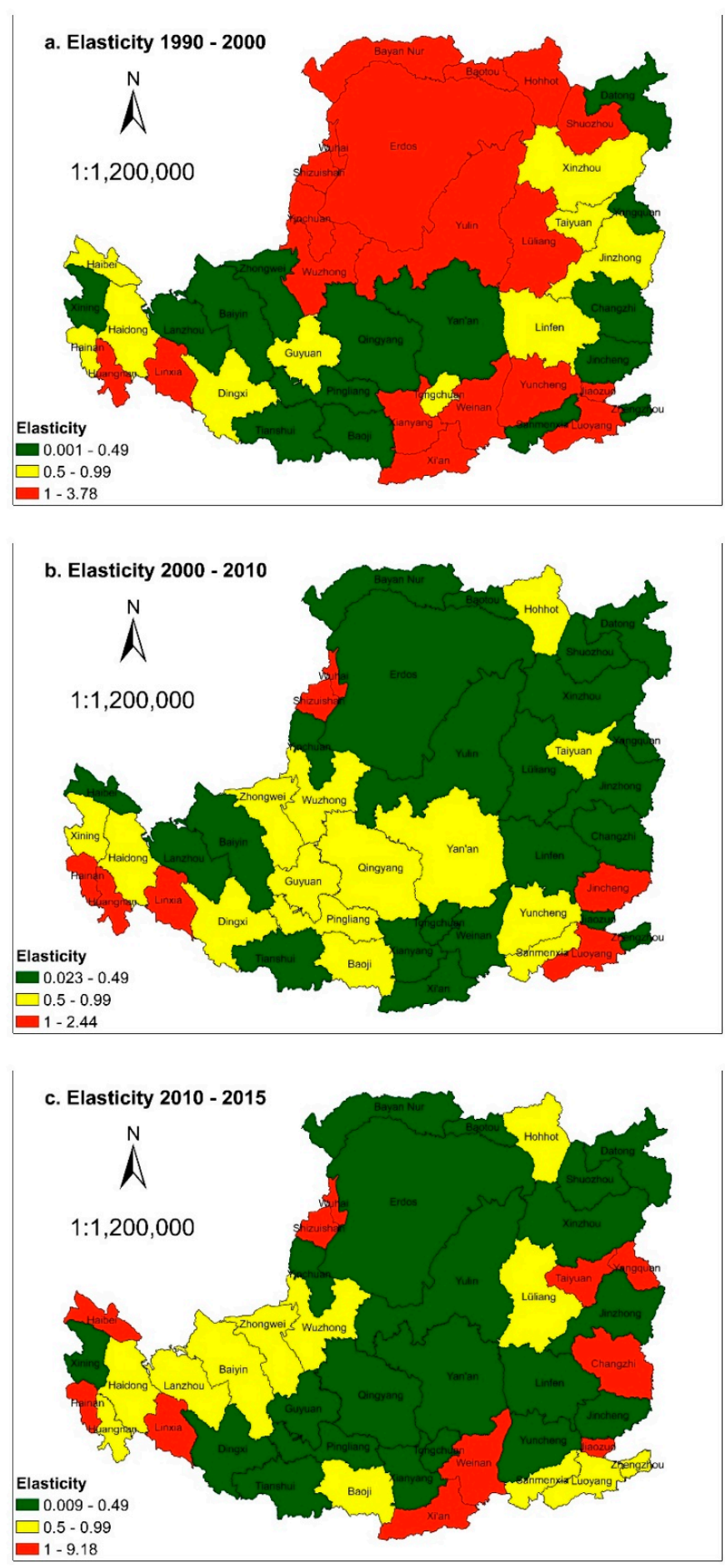

Figure 6. Municipal elasticity in the three periods. 


\section{Discussion}

\subsection{The Implications for Policy-Making}

Since elasticity is an indicator that reflects the response of ESV changes to LULC conversions, it is helpful for detecting unusual changes among different regions and identifying policy needs for ecosystem management. Taking Linxia as an example, its elasticity was 9.18 from 2010 to 2015 (Table 4). In 2010, the central part of Linxia was mainly covered by dry farmland (ca. 46\%); prairies, shrub grass and bare land were widely distributed in the northern region, while bush and meadows were located in the southern region. Note that a large lake was found in the north-central region (Figure 7). Between 2010 and 2015, Linxia experienced substantial ESV growth by around \$4.536 million, which could be attributed to the expansion of the lake. On the one hand, the conversion of 1468 ha of bare land, shrub grass and dry farmland to rivers and lakes resulted in an ESV increase of around $\$ 4.537$ million; on the other hand, it should be noted that the expansion of 597 ha of built-up areas from dry farmland led to around \$1 million in ESV reductions (Table 6). Considering the ecological importance and economic value of rivers and lakes, the effective protection and management of the lake in Linxia is urgently needed for policy-making, such as establishing a protected area $[45,46]$ in order to avoid its shrinkage and occupation by other LULC types during the progress of urbanization.

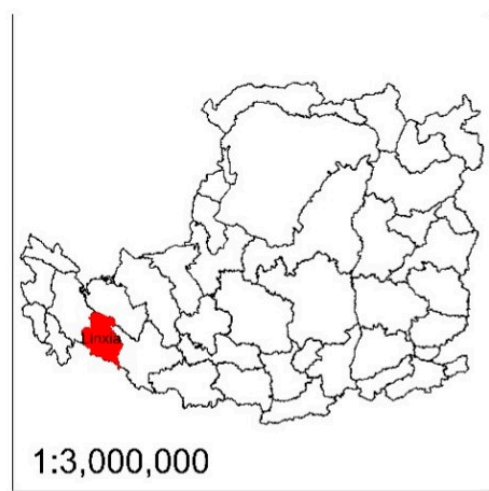

LULC

Dry farmland Prairie

Shrub grass

Bush

Meadow

Bare land

Built up area

River and lake

Coniferous forest

Mixed forest

Broad-leaved forest

Wetland

Paddy ficlo

Total

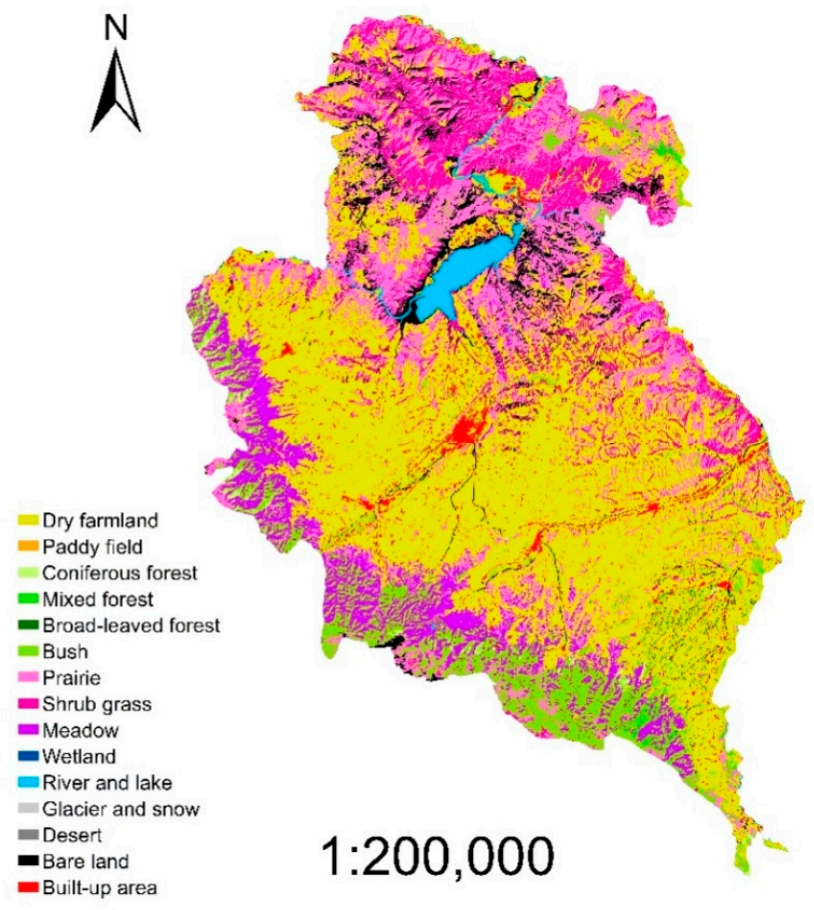

Figure 7. The distribution of LULC in Linxia in 2010.

Table 6. LULC and ESV changes in Linxia from 2010 to 2015.

\begin{tabular}{ccc}
\hline LULC Change & Area (ha) & ESV Change (millions of \$) \\
\hline Bare land-River/lake & 1040.15 & 4513.26 \\
\hline Shrub grass-River/lake & 419.94 & 22.38 \\
\hline Dry farmland-River/lake & 25.69 & 1.57 \\
\hline Dry farmland-Shrub grass & 0.09 & 0.001 \\
\hline Dry farmland-Built-up area & 597.24 & -1.21 \\
\hline Total & 2083.12 & 4536.01 \\
\hline
\end{tabular}


Another example is Shizuishan: its elasticity was 2.46 from 2010 to 2015 (Table 4). In 2010, the central region was covered by dry farmland, paddy fields, built-up areas and rivers/lakes; bare land and grasslands (e.g., prairies and shrub grass) were widely distributed in the western region, and deserts could be found at the northwestern and eastern edges (Figure 8). Between 2010 and 2015, Shizuishan witnessed a considerable reduction in ESVs by ca. \$130 million; the unit value loss even reached \$13,076/ha. The ESV loss mainly resulted from the large occupation of rivers and lakes (ca. 2200 ha) and the rapid expansion of built-up areas (ca. 3100 ha), which led to ESV decreases of ca. \$135 and \$20 million, respectively (Table 7). Hence, the effective management of rivers and lakes and appropriate urban planning for Shizuishan are urgently needed. Decision-makers should keep in mind that the occupation of highly valuable lands such as rivers and lakes must be avoided during the urbanization process.

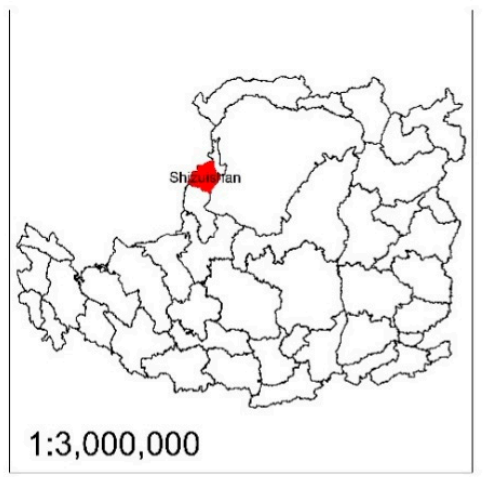

LULC

Dry Tarmland

Bare land

Prairie

Shrub grass

Built up area

Paddy l'ield

Bush

River and lake

Desert

Coniferous forest

Hetland

Total

$\begin{array}{rr}\text { Area (ha) } & \text { Percent } \\ 99731 & 25.09 \% \\ 77401 & 19.17 \% \\ 18213 & 12.11 \% \\ 39100 & 9.91 \% \\ 37665 & 9.18 \% \\ 32117 & 8.16 \% \\ 23456 & 5.90 \% \\ 16270 & 4.09 \% \\ 14805 & 3.72 \% \\ 5734 & 1.41 \% \\ 2356 & 0.59 \% \\ 397483 & 100.00 \%\end{array}$

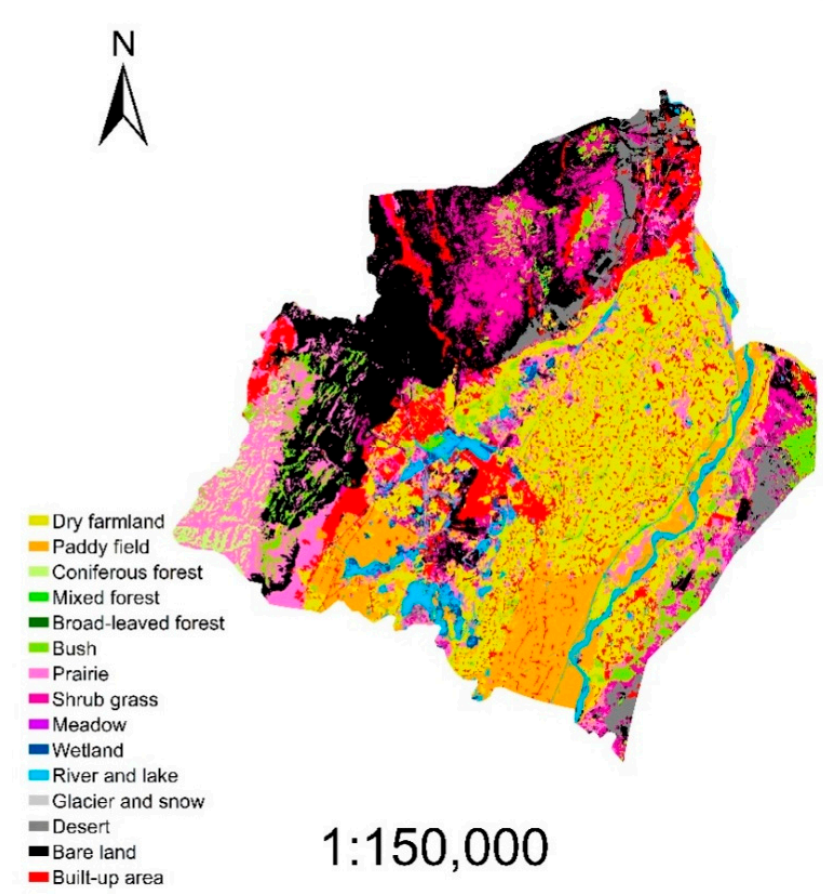

Figure 8. The distribution of LULC in Shizuishan in 2010.

Table 7. LULC and ESV changes in Shizuishan from 2010 to 2015.

\begin{tabular}{ccc}
\hline LULC Change & Area (ha) & ESV Change (millions of \$) \\
\hline River/lake-Bare land & 989.76 & -62.46 \\
\hline River/lake-Paddy field & 519.45 & -31.82 \\
\hline River/lake-Prairie & 340.01 & -20.62 \\
\hline River/lake-Shrub grass & 288.15 & -15.36 \\
\hline Shrub grass-Built-up area & 987.35 & -9.78 \\
\hline River/lake-Built-up area & 70.28 & -4.44 \\
\hline Wetland-Prairie & 67.54 & -1.60 \\
\hline Bush-Built-up area & 169.24 & -1.30 \\
\hline Prairie-Built-up area & 497.03 & -1.27 \\
\hline Dry farmland-Built-up area & 570.24 & -1.15 \\
\hline Wetland-Built-up area & 41.67 & -1.09 \\
\hline Wetland-Paddy field & 27.30 & -0.66 \\
\hline River/lake-Bush & 9.03 & -0.50 \\
\hline Wetland-Bare land & 17.25 & -0.45 \\
\hline
\end{tabular}


Table 7. Cont.

\begin{tabular}{|c|c|c|}
\hline LULC Change & Area (ha) & ESV Change (millions of \$) \\
\hline Paddy field-Bare land & 183.97 & -0.34 \\
\hline Coniferous forest-Built-up area & 37.03 & -0.33 \\
\hline Wetland-Shrub grass & 15.69 & -0.26 \\
\hline Paddy field-Built-up area & 111.84 & -0.22 \\
\hline Shrub grass-Desert & 15.74 & -0.15 \\
\hline Dry farmland-Bare land & 43.29 & -0.08 \\
\hline Bush-Prairie & 16.15 & -0.08 \\
\hline Bare land-Built-up area & 569.28 & -0.06 \\
\hline Desert-Built-up area & 99.97 & -0.06 \\
\hline Wetland-Dry farmland & 1.76 & -0.04 \\
\hline Bush-Bare land & 3.01 & -0.02 \\
\hline Dry farmland-Desert & 3.06 & -0.0045 \\
\hline Desert-Bare land & 1.45 & -0.0007 \\
\hline Prairie-Desert & 0.22 & -0.0004 \\
\hline Dry farmland-Bush & 0.18 & 0.0010 \\
\hline Paddy field-Bush & 1.28 & 0.01 \\
\hline Dry farmland-Prairie & 14.06 & 0.01 \\
\hline Paddy field-Dry farmland & 159.00 & 0.01 \\
\hline Prairie-Shrub grass & 1.68 & 0.01 \\
\hline Bush-Shrub grass & 6.44 & 0.01 \\
\hline Bare land-Prairie & 8.01 & 0.02 \\
\hline Paddy field-Shrub grass & 8.05 & 0.06 \\
\hline Bare land-Shrub grass & 31.73 & 0.31 \\
\hline Paddy field-Prairie & 528.14 & 0.31 \\
\hline Dry farmland-Shrub grass & 71.40 & 0.56 \\
\hline Dry farmland-River/lake & 162.90 & 9.97 \\
\hline Wetland-River/lake & 338.12 & 12.52 \\
\hline Total & 7027.74 & -130.32 \\
\hline
\end{tabular}

\subsection{The Driving Factors for LULC Conversion on the LP}

LULC conversion on the LP is influenced by internal natural and external socioeconomic driving factors. Natural factors include altitude, slope, annual temperatures and annual precipitation. Altitude is the common dominant factor associated with changes in forestlands (including coniferous forests, mixed forests, broad-leaved forests and the bush), grasslands (including prairies, shrub grass and meadows), cropland (including dry farmland and paddy fields) and built-up areas. Altitude and slope are positively related to forestland conversion but negatively related to cropland conversion in the central region. Annual temperatures and annual precipitation positively affect forestland and grassland conversion in the northwestern region [47].

Socioeconomic factors include population growth (including population density, urban populations and rural populations), industry structure (including primary industries and secondary industries), economic indicators (including GDP and farmer income) and GFGP policies (including afforestation areas, fiscal revenue and fiscal expenditure). From 1990 to 2000, the change in forestlands was mainly affected by population density and primary industries; the conversion of grasslands was determined by urban populations and population density; the expansion of cropland and built-up areas depended on urban and rural populations, population density, farmer income and GDP growth. Between 2000 and 2015, urban populations and population density were responsible for forestland conversion; afforestation areas, fiscal expenditure, GDP growth and urban populations were the main 
driving forces for grassland conversion; farmer income, primary industries and population density affected the conversion of cropland; and population density, GDP growth, fiscal expenditure and fiscal revenue determined the expansion of built-up areas [47]. In total, ecological restoration policies contributed about $72 \%$, and the natural environment contributed about $28 \%$ to LULC changes on the LP, indicating that the GFGP had a profound impact on LULC conversion [48].

\subsection{The Improvement of Accuracy}

It is obvious that the quality of LULC data and the precision of unit values of ecosystem services provided by different LULC types determine the accuracy of the assessment. An improvement should consider both aspects. Misclassification errors based on LULC data may lead to bias in area estimates, further resulting in significantly faulty calculations of LULC conversion. Besides, data validation is often rare or inadequately undertaken because its importance is overlooked [49,50]. Furthermore, the consistency and comparability among different LULC datasets are limited by the lack of classification standards [51]. Hence, enhancing the resolution and precision of LULC datasets with validation and standardization of LULC classification systems towards harmonization are important directions in future studies.

To improve the unit ESVs of LULC types, the first step is to ensure completeness by taking more LULC types into account, such as urban types because an urban ecosystem also provides multiple valuable ecosystem services [52,53]. The development of dynamic unit ESVs is an effort made for improving precision, which can be used for assessing monthly or seasonal variations in ESVs within a given year when the LULC does not obviously change [40]. For the comparison of ESVs among different years, especially over quite a long period when the LULC has significantly changed, dynamic unit values are not appropriate. Thus, the other way is the expansion of the database to consist of more and more empirical studies based on physical modeling and environmental valuation techniques [8]. The amount of high-quality primary studies is the key basis for the benefit transfer method.

\section{Conclusions}

The LP is not only a vulnerable region that suffers from ecological threats, like soil erosion and water shortages, but also a valuable region that provides a variety of fundamental ecosystem services to a large population in China. Various natural and socioeconomic factors have significantly changed the pattern of LULC on the LP from 1990 to 2015. Based on the combined approach of LULC proxies and the benefit transfer method, we assessed the ESV changes in response to LULC conversion, revealing that the total ESV has been reduced by $\$ 6.787$ million from 1990 to 2000 and increased by $\$ 4.6$ million after the implementation of the GFGP from 2000 to 2015 . We also showed that a $1 \%$ area conversion has resulted in $1.03 \%, 0.38 \%$ and $0.05 \%$ ESV changes in the 1990-2000, 2000-2010 and 2010-2015 periods, respectively. We suggested that elasticity as a simplified indicator is helpful for detecting unusual changes among different regions and identifying specific policy needs for ecosystem management, such as in the cases of Linxia and Shizuishan. Appropriate ecosystem management not only enhances ecosystem service supply but also contributes to regional sustainable development. An increase in the accuracy of results should be considered from the perspectives of LULC data quality and unit ESV precision in the future.

Author Contributions: Conceptualization, W.J.; methodology, W.J.; software, W.J.; validation, W.J.; formal analysis, W.J.; investigation, W.J.; resources, W.J.; data curation, W.J.; writing—original draft preparation, W.J.; writing - review and editing, W.J.; visualization, W.J.; supervision, Y.L.; project administration, B.F.; funding acquisition, B.F. All authors have read and agreed to the published version of the manuscript.

Funding: This research was funded by the National Natural Science Foundation of China, grant number 41930649.

Acknowledgments: This research was supported by the National Natural Science Foundation of China (No. 41930649). Many thanks are also given to Jiamei Xiao, who made some important tables.

Conflicts of Interest: The authors declare no conflict of interest. 


\section{Appendix A}
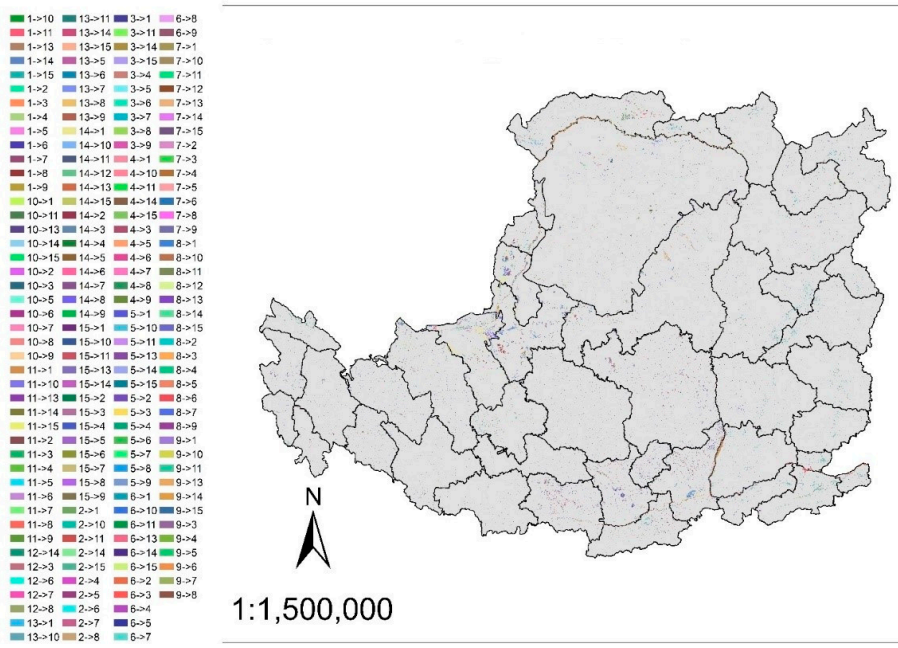

$1: 1,500,000$

Figure A1. Distribution of changed areas from 1990 to 2000.

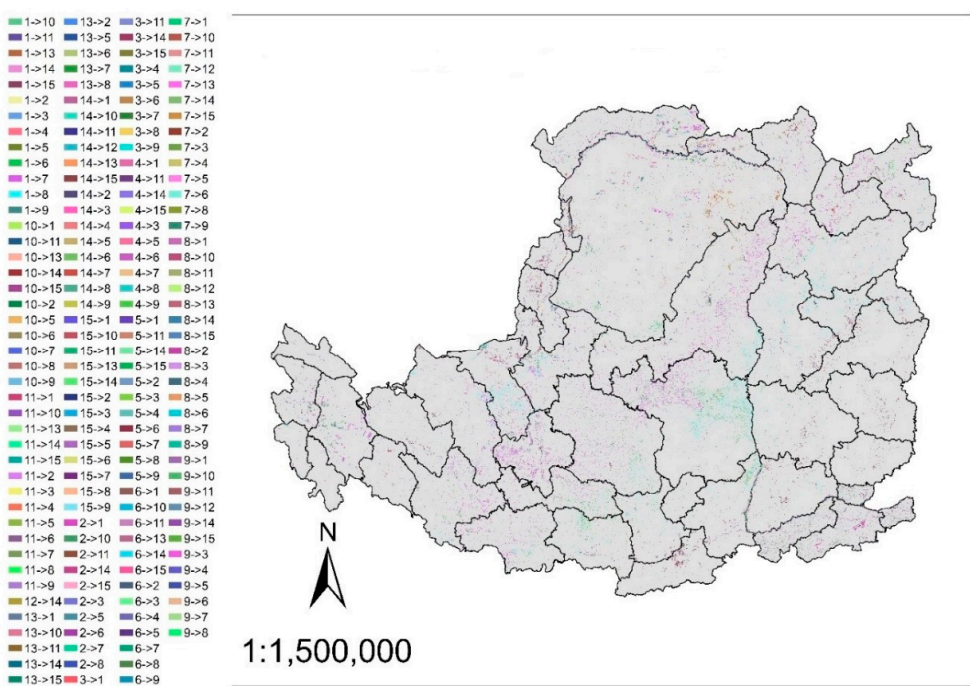

Figure A2. Distribution of changed areas from 2000 to 2010.

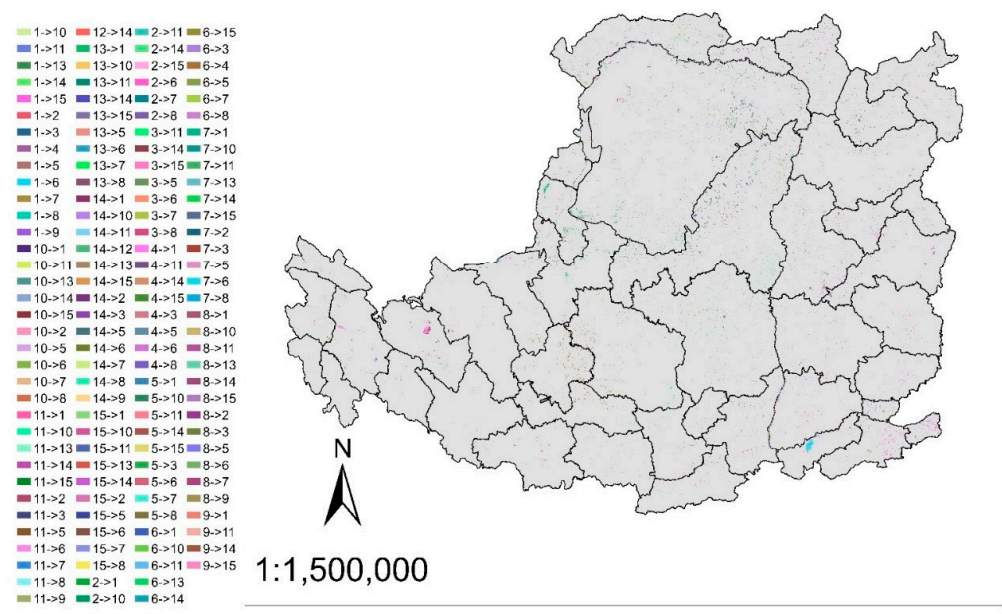

Figure A3. Distribution of changed areas from 2010 to 2015. 
Table A1. Transition matrix from 1990 to 2000 (unit: ha).

\begin{tabular}{|c|c|c|c|c|c|c|c|c|c|c|c|c|c|c|c|}
\hline From To & $\begin{array}{c}\text { Dry } \\
\text { Farmland }\end{array}$ & $\begin{array}{l}\text { Paddy } \\
\text { Field }\end{array}$ & $\begin{array}{l}\text { Coniferous } \\
\text { Forest }\end{array}$ & $\begin{array}{l}\text { Mixed } \\
\text { Forest }\end{array}$ & $\begin{array}{c}\text { Broad-Leaved } \\
\text { Forest }\end{array}$ & Bush & Prairie & $\begin{array}{l}\text { Shrub } \\
\text { Grass }\end{array}$ & Meadow & Wetland & $\begin{array}{l}\text { River and } \\
\text { Lake }\end{array}$ & $\begin{array}{c}\text { Glacier } \\
\text { and Snow }\end{array}$ & Desert & Bare Land & $\begin{array}{c}\text { Built-Up } \\
\text { Area }\end{array}$ \\
\hline Dry farmland & - & 1987 & 148 & 516 & 9546 & 54,646 & 55,740 & 80,831 & 2073 & 1732 & 20,191 & 0 & 103 & 13,628 & 149,663 \\
\hline Paddy field & 8208 & - & 0 & 2 & 1 & 235 & 208 & 73 & 0 & 112 & 811 & 0 & 0 & 21 & 1772 \\
\hline Coniferous forest & 121 & 0 & - & 153 & 788 & 1732 & 227 & 661 & 149 & 0 & 16 & 0 & 0 & 30 & 13 \\
\hline Mixed forest & 315 & 0 & 259 & - & 2410 & 1208 & 36 & 274 & 9 & 1 & 36 & 0 & 0 & 25 & 38 \\
\hline Broad-leaved forest & 2721 & 0 & 762 & 909 & - & 7666 & 998 & 2233 & 74 & 0 & 79 & 0 & 10 & 101 & 356 \\
\hline Bush & 23,520 & 30 & 1321 & 707 & 7781 & - & 13,140 & 11,528 & 1682 & 90 & 619 & 0 & 2979 & 839 & 3201 \\
\hline Prairie & 74,943 & 848 & 192 & 32 & 822 & 10,057 & - & 13,438 & 843 & 1044 & 2576 & 1 & 6141 & 5272 & 10,663 \\
\hline Shrub grass & 107,384 & 5365 & 646 & 223 & 2562 & 20,085 & 22,741 & - & 118 & 514 & 4003 & 23 & 6697 & 18,583 & 19,445 \\
\hline Meadow & 1179 & 0 & 62 & 2 & 12 & 1175 & 708 & 112 & - & 7 & 3 & 0 & 0 & 182 & 103 \\
\hline Wetland & 7630 & 199 & 1 & 0 & 14 & 308 & 952 & 594 & 29 & - & 8020 & 0 & 3 & 1760 & 199 \\
\hline River and lake & 75,876 & 5346 & 6 & 66 & 423 & 3280 & 8405 & 10,936 & 7 & 10,818 & - & 0 & 729 & 37,079 & 2820 \\
\hline Glacier and snow & 0 & 0 & 0 & 0 & 0 & 1 & 2 & 0 & 0 & 0 & 0 & - & 0 & 6776 & 0 \\
\hline Desert & 5387 & 0 & 0 & 0 & 10 & 4900 & 14,641 & 20,722 & 1 & 42 & 22 & 0 & - & 416 & 398 \\
\hline Bare land & 111,765 & 5748 & 22 & 21 & 166 & 5552 & 9969 & 20,863 & 171 & 1007 & 13,916 & 1438 & 111 & - & 8263 \\
\hline Built-up area & 7456 & 67 & 15 & 5 & 224 & 504 & 788 & 806 & 10 & 6 & 97 & 0 & 12 & 147 & - \\
\hline
\end{tabular}


Table A2. Transition matrix from 2000 to 2010 (unit: ha).

\begin{tabular}{|c|c|c|c|c|c|c|c|c|c|c|c|c|c|c|c|}
\hline From $\quad$ To & $\begin{array}{c}\text { Dry } \\
\text { Farmland }\end{array}$ & $\begin{array}{l}\text { Paddy } \\
\text { Field }\end{array}$ & $\begin{array}{c}\text { Coniferous } \\
\text { Forest }\end{array}$ & $\begin{array}{l}\text { Mixed } \\
\text { Forest }\end{array}$ & $\begin{array}{c}\text { Broad-Leaved } \\
\text { Forest }\end{array}$ & Bush & Prairie & $\begin{array}{l}\text { Shrub } \\
\text { Grass }\end{array}$ & Meadow & Wetland & $\begin{array}{l}\text { River and } \\
\text { Lake }\end{array}$ & $\begin{array}{c}\text { Glacier } \\
\text { and Snow }\end{array}$ & Desert & Bare Land & $\begin{array}{c}\text { Built-Up } \\
\text { Area }\end{array}$ \\
\hline Dry farmland & - & 8706 & 577 & 1252 & 27,139 & 232,021 & 595,344 & 320,514 & 16,900 & 6967 & 40,955 & 0 & 306 & 36,357 & 254,592 \\
\hline Paddy field & 9912 & - & 0 & 0 & 17 & 214 & 102 & 43 & & 29 & 1709 & 0 & 0 & 76 & 1192 \\
\hline Coniferous forest & 84 & 0 & - & 157 & 2099 & 707 & 35 & 307 & 4 & 0 & 13 & 0 & 0 & 16 & 80 \\
\hline Mixed forest & 141 & 0 & 147 & - & 925 & 544 & 18 & 237 & 0 & 0 & 5 & 0 & 0 & 5 & 37 \\
\hline Broad-leaved forest & 2089 & 3 & 2773 & 874 & - & 10,033 & 496 & 1791 & 0 & 0 & 222 & 0 & 0 & 243 & 677 \\
\hline Bush & 11,926 & 4 & 928 & 664 & 13,485 & - & 6004 & 8944 & 124 & 27 & 725 & 0 & 668 & 1280 & 8654 \\
\hline Prairie & 58,295 & 692 & 181 & 20 & 728 & 13,773 & - & 8518 & 235 & 1731 & 6308 & 1 & 4097 & 13,008 & 75,909 \\
\hline Shrub grass & 45,516 & 1790 & 225 & 292 & 2124 & 19,979 & 17,254 & - & 12 & 1081 & 10,787 & 6 & 6484 & 12,744 & 54,031 \\
\hline Meadow & 60 & 0 & 13 & 1 & 0 & 566 & 165 & 2 & - & 0 & 23 & 2 & 0 & 6 & 319 \\
\hline Wetland & 3758 & 78 & 0 & 0 & 96 & 627 & 2257 & 764 & 0 & - & 8015 & 0 & 6 & 1669 & 1030 \\
\hline River and lake & 21,206 & 3324 & 27 & 19 & 155 & 2411 & 5804 & 5545 & 5 & 10,028 & - & 0 & 110 & 18,747 & 4779 \\
\hline Glacier and snow & 0 & 0 & 0 & 0 & 0 & 0 & 0 & 0 & 0 & 0 & 0 & - & 0 & 0 & 0 \\
\hline Desert & 2300 & 30 & 192 & 2193 & 12,381 & 15,616 & 0 & 0 & 0 & 127 & 167 & 0 & - & 521 & 4260 \\
\hline Bare land & 30,622 & 584 & 13 & 18 & 361 & 3921 & 12,391 & 14,113 & 130 & 3567 & 26,562 & 2878 & 580 & - & 24,159 \\
\hline Built-up area & 10,118 & 636 & 1 & 3 & 68 & 347 & 114 & 470 & 1 & 11 & 233 & 0 & 1 & 86 & - \\
\hline
\end{tabular}


Table A3. Transition matrix from 2010 to 2015 (unit: ha).

\begin{tabular}{|c|c|c|c|c|c|c|c|c|c|c|c|c|c|c|c|}
\hline From $\quad$ To & $\begin{array}{c}\text { Dry } \\
\text { Farmland }\end{array}$ & $\begin{array}{l}\text { Paddy } \\
\text { Field }\end{array}$ & $\begin{array}{l}\text { Coniferous } \\
\text { Forest }\end{array}$ & $\begin{array}{l}\text { Mixed } \\
\text { Forest }\end{array}$ & $\begin{array}{c}\text { Broad-Leaved } \\
\text { Forest }\end{array}$ & Bush & Prairie & $\begin{array}{l}\text { Shrub } \\
\text { Grass }\end{array}$ & Meadow & Wetland & $\begin{array}{l}\text { River and } \\
\text { Lake }\end{array}$ & $\begin{array}{c}\text { Glacier } \\
\text { and Snow }\end{array}$ & Desert & Bare Land & $\begin{array}{c}\text { Built-Up } \\
\text { Area }\end{array}$ \\
\hline Dry farmland & - & 1466 & 0 & 1 & 833 & 24,214 & 117,626 & 50,456 & 2576 & 1358 & 21,071 & 0 & 58 & 15,245 & 106,479 \\
\hline Paddy field & 577 & - & 0 & 0 & 0 & 401 & 598 & 35 & 0 & 0 & 2403 & 0 & 0 & 243 & 4878 \\
\hline Coniferous forest & 0 & 0 & - & 0 & 3 & 16 & 10 & 5 & 0 & 0 & 5 & 0 & 0 & 12 & 476 \\
\hline Mixed forest & 32 & 0 & 0 & - & 0 & 1 & 0 & 44 & 0 & 0 & 0 & 0 & 0 & 17 & 347 \\
\hline Broad-leaved forest & 795 & 0 & 2 & 0 & - & 94 & 107 & 198 & 0 & 0 & 111 & 0 & 0 & 443 & 2006 \\
\hline Bush & 9877 & 0 & 9 & 0 & 2835 & - & 1375 & 745 & 0 & 88 & 949 & 0 & 96 & 3043 & 15,688 \\
\hline Prairie & 64,399 & 5 & 0 & 0 & 72 & 2868 & - & 2765 & 0 & 157 & 5665 & 0 & 715 & 12,980 & 61,211 \\
\hline Shrub grass & 33,188 & 0 & 0 & 0 & 100 & 1552 & 3538 & - & 5 & 323 & 5751 & 0 & 1622 & 20,920 & 40,445 \\
\hline Meadow & 199 & 0 & 0 & 0 & 0 & 0 & 0 & 0 & - & 0 & 265 & 0 & 0 & 1170 & 213 \\
\hline Wetland & 3183 & 66 & 0 & 0 & 24 & 277 & 1819 & 554 & 0 & - & 13,052 & 0 & 6 & 2248 & 654 \\
\hline River and lake & 8542 & 2103 & 1 & 0 & 28 & 1120 & 6936 & 5251 & 26 & 4903 & - & 0 & 117 & 17,418 & 624 \\
\hline Glacier and snow & 0 & 0 & 0 & 0 & 0 & 0 & 0 & 0 & 0 & 0 & 0 & - & 0 & 454 & 0 \\
\hline Desert & 5372 & 0 & 0 & 0 & 55 & 3780 & 12,277 & 13,866 & 0 & 67 & 98 & 0 & - & 3146 & 5759 \\
\hline Bare land & 11,939 & 58 & 0 & 0 & 21 & 1879 & 7017 & 6481 & 96 & 1216 & 16,630 & 0 & 2921 & - & 10,478 \\
\hline Built-up area & 38 & 0 & 0 & 0 & 2 & 39 & 7 & 31 & 0 & 3 & 660 & 0 & 1 & 14 & - \\
\hline
\end{tabular}



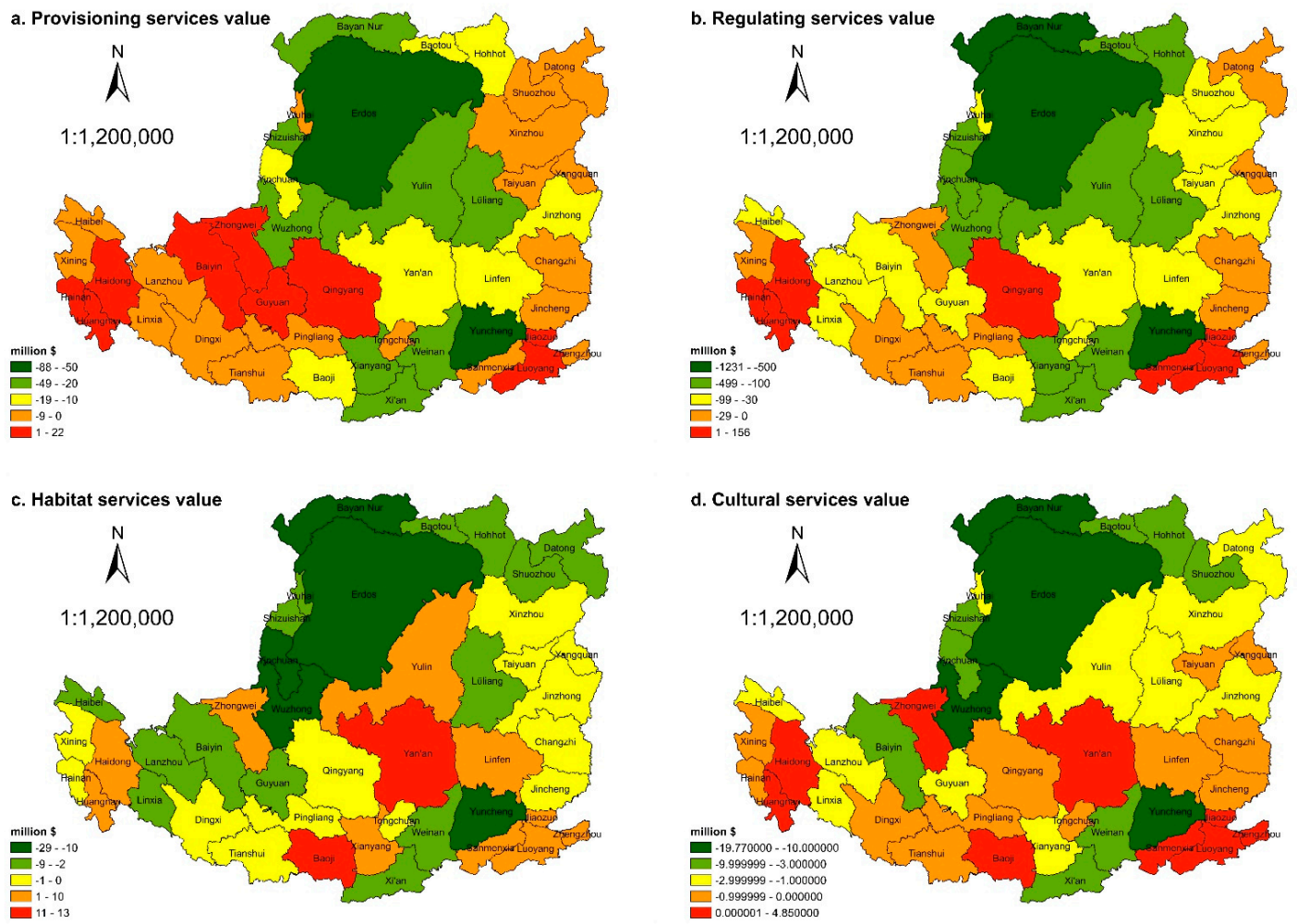

Figure A4. ESV changes from 1990 to 2000.
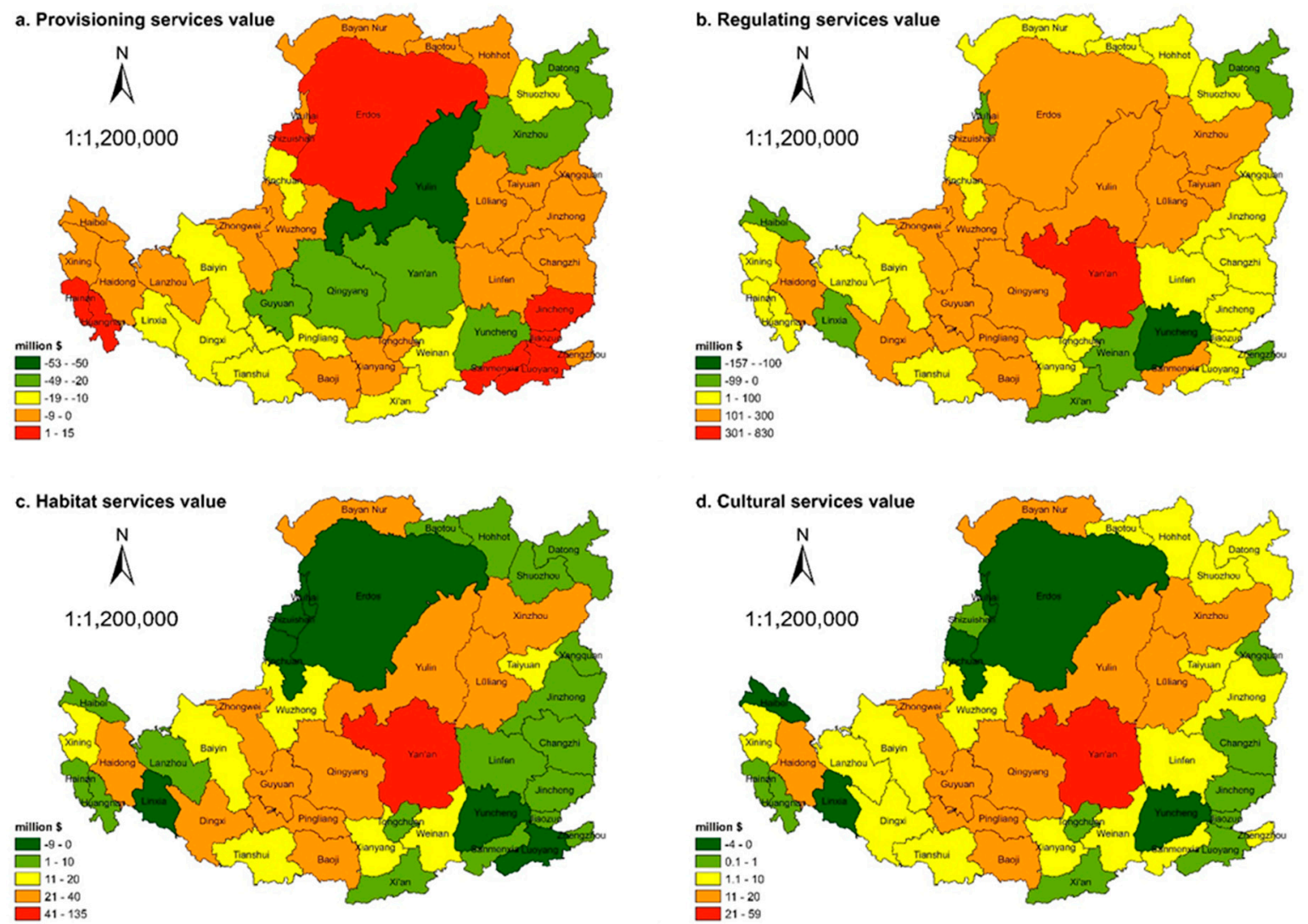

Figure A5. ESV changes from 2000 to 2010. 

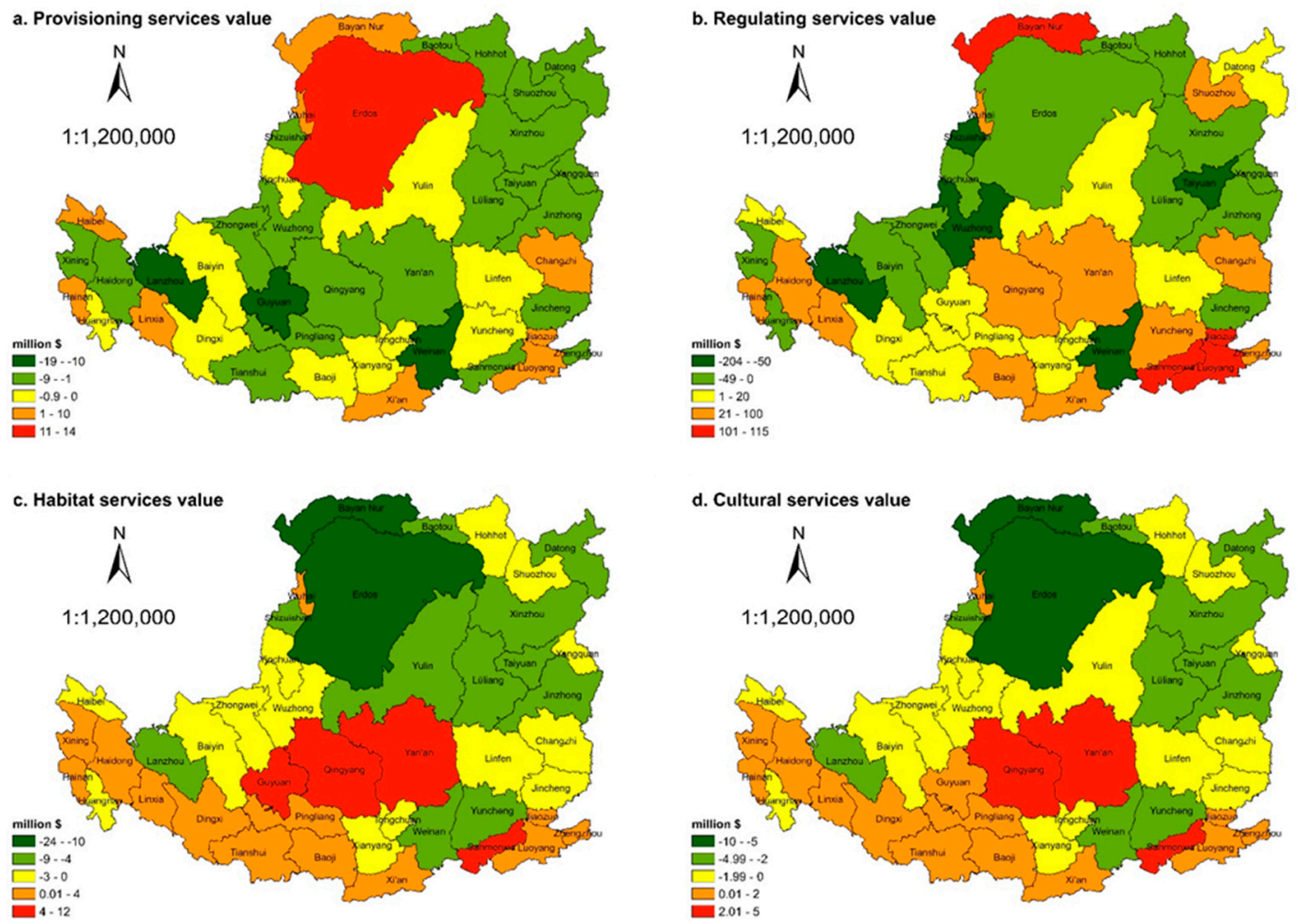

Figure A6. ESV changes from 2010 to 2015.

\section{References}

1. Millennium ecosystem assessment. In Ecosystems and Human Well-Being: Synthesis; Island Press: Washington, DC, USA, 2005.

2. The Economics of Ecosystems and Biodiversity: Mainstreaming the Economics of Nature: A synthesis of the Approach, Conclusions and Recommendations of TEEB; UNEP: Nairobi, Kenya, 2010.

3. Costanza, R.; D’Arge, R.; De Groot, R.; Farber, S.; Grasso, M.; Hannon, B.; Limburg, K.; Naeem, S.; O’Neill, R.V.; Paruelo, J.; et al. The value of the world's ecosystem services and natural capital. Nature 1997, 387, $253-260$. [CrossRef]

4. De Groot, R.; Brander, L.; Van Der Ploeg, S.; Costanza, R.; Bernard, F.; Braat, L.; Christie, M.; Crossman, N.; Ghermandi, A.; Hein, L.; et al. Global estimates of the value of ecosystems and their services in monetary units. Ecosyst. Serv. 2012, 1, 50-61. [CrossRef]

5. Bateman, I.J.; Harwood, A.R.; Mace, G.M.; Watson, R.T.; Abson, D.J.; Andrews, B.; Binner, A.; Crowe, A.; Day, B.H.; Dugdale, S.; et al. Bringing ecosystem services into economic decision-making: Land use in the United Kingdom. Science 2013, 341, 45-50. [CrossRef] [PubMed]

6. Fu, B.; Zhang, L.; Xu, Z.; Zhao, Y.; Wei, Y.; Skinner, D. Ecosystem services in changing land use. J. Soils Sediments 2015, 15, 833-843. [CrossRef]

7. Costanza, R.; De Groot, R.; Sutton, P.; Van der Ploeg, S.; Anderson, S.J.; Kubiszewski, I.; Farber, S.; Turner, R.K. Changes in the global value of ecosystem services. Glob. Environ. Chang. 2014, 26, 152-158. [CrossRef]

8. Schägner, J.; Brander, L.; Maes, J.; Hartje, V. Mapping ecosystem services' values: Current practice and future prospects. Ecosyst. Serv. 2013, 4, 33-46. [CrossRef]

9. Kindu, M.; Schneider, T.; Teketay, D.; Knoke, T. Changes of ecosystem service values in response to land use/land cover dynamics in Munessa-Shashemene landscape of the Ethiopian highlands. Sci. Total Environ. 2016, 547, 137-147. [CrossRef]

10. Song, W.; Deng, X. Land-use/land-cover change and ecosystem service provision in China. Sci. Total Environ. 2017, 576, 705-719. [CrossRef]

11. Arowolo, A.O.; Deng, X.; Olatunji, O.A.; Obayelu, A.E. Assessing changes in the value of ecosystem services in response to land-use/land-cover dynamics in Nigeria. Sci. Total Environ. 2018, 636, 597-609. [CrossRef] 
12. Zhang, F.; Yushanjiang, A.; Jing, Y. Assessing and predicting changes of the ecosystem service values based on land use/cover change in Ebinur Lake Wetland National Nature Reserve, Xinjiang, China. Sci. Total Environ. 2019, 656, 1133-1144. [CrossRef]

13. Qiu, B.; Li, H.; Zhou, M.; Zhang, L. Vulnerability of ecosystem services provisioning to urbanization: A case of China. Ecol. Indic. 2015, 57, 505-513. [CrossRef]

14. Liu, W.; Yan, Y.; Wang, D.; Ma, W. Integrate carbon dynamics models for assessing the impact of land use intervention on carbon sequestration ecosystem service. Ecol. Indic. 2018, 91, 268-277. [CrossRef]

15. Salata, S.; Ronchi, S.; Arcidiacono, A. Mapping air filtering in urban areas. A Land Use Regression model for Ecosystem Services assessment in planning. Ecosyst. Serv. 2017, 28, 341-350. [CrossRef]

16. Brauman, K.A.; Freyberg, D.L.; Daily, G. Impacts of Land-Use Change on Groundwater Supply: Ecosystem Services Assessment in Kona, Hawaii. J. Water Resour. Plann. Manag. 2015, 141. [CrossRef]

17. Lavelle, P.; Rodríguez, N.; Arguello, O.; Bernal, J.; Botero, C.; Chaparro, P.; Gómez, Y.; Gutiérrez, A.; Del Pilar Hurtado, M.; Loaiza, S.; et al. Soil ecosystem services and land use in the rapidly changing Orinoco River Basin of Colombia. Agric. Ecosyst. Environ. 2014, 185, 106-117. [CrossRef]

18. Butler, J.R.A.; Wong, G.Y.; Metcalfe, D.J.; Honzák, M.; Pert, P.L.; Rao, N.; Van Grieken, M.E.; Lawson, T.; Bruce, C.; Kroon, F.J.; et al. An analysis of trade-offs between multiple ecosystem services and stakeholders linked to land use and water quality management in the Great Barrier Reef, Australia. Agric. Ecosyst. Environ. 2013, 180, 176-191. [CrossRef]

19. Bozzola, M.; Massetti, E.; Mendelsohn, R.; Capitanio, F. A Ricardian analysis of the impact of climate change on Italian agriculture. Eur. Rev. Agric. Econ. 2018, 45, 57-79. [CrossRef]

20. Chavas, J.-P.; Di Falco, S.; Adinolfi, F.; Capitanio, F. Weather effects and their long-term impact on the distribution of agricultural yields: Evidence from Italy. Eur. Rev. Agric. Econ. 2019, 46, 29-51. [CrossRef]

21. Capitanio, F.; Gatto, E.; Millemaci, E. CAP payments and spatial diversity in cereal crops: An analysis of Italian farms. Land Use Policy 2016, 54, 574-582. [CrossRef]

22. Pascucci, S.; de-Magistris, T.; Dries, L.; Adinolfi, F.; Capitanio, F. Participation of Italian farmers in rural development policy. Eur. Rev. Agric. Econ. 2013, 40, 605-631. [CrossRef]

23. Cumming, G.S.; Buerkert, A.; Hoffmann, E.M.; Schlecht, E.; Von Cramon-Taubadel, S.; Tscharntke, T. Implications of agricultural transitions and urbanization for ecosystem services. Nature 2014, 515, 50-57. [CrossRef] [PubMed]

24. Cariveau, D.P.; Williams, N.M.; Benjamin, F.E.; Winfree, R. Response diversity to land use occurs but does not consistently stabilize ecosystem services provided by native pollinators. Ecol. Lett. 2013, 16, 903-911. [CrossRef] [PubMed]

25. Fontana, V.; Radtke, A.; Walde, J.; Tasser, E.; Wilhalm, T.; Zerbe, S.; Tappeiner, U. What plant traits tell us: Consequences of land-use change of a traditional agro-forest system on biodiversity and ecosystem service provision. Agric. Ecosyst. Environ. 2014, 186, 44-53. [CrossRef]

26. Byrd, K.B.; Flint, L.E.; Alvarez, P.; Casey, C.F.; Sleeter, B.M.; Soulard, C.E.; Flint, A.L.; Sohl, T.L. Integrated climate and land use change scenarios for California rangeland ecosystem services: Wildlife habitat, soil carbon, and water supply. Landsc. Ecol 2015, 30, 729-750. [CrossRef]

27. Feng, X.; Fu, B.; Lu, N.; Zeng, Y.; Wu, B. How ecological restoration alters ecosystem services: An analysis of carbon sequestration in China's Loess Plateau. Sci. Rep. 2013, 3, 2846. [CrossRef]

28. Wu, D.; Zou, C.; Cao, W.; Xiao, T.; Gong, G. Ecosystem services changes between 2000 and 2015 in the Loess Plateau, China: A response to ecological restoration. PLoS ONE 2019, 14, e0209483. [CrossRef]

29. Jiang, C.; Zhang, H.; Zhang, Z. Spatially explicit assessment of ecosystem services in China's Loess Plateau: Patterns, interactions, drivers, and implications. Glob. Planet. Chang. 2018, 161, 41-52. [CrossRef]

30. Wei, H.; Fan, W.; Ding, Z.; Weng, B.; Xing, K.; Wang, X.; Lu, N.; Ulgiati, S.; Dong, X. Ecosystem Services and Ecological Restoration in the Northern Shaanxi Loess Plateau, China, in Relation to Climate Fluctuation and Investments in Natural Capital. Sustainability 2017, 9, 199. [CrossRef]

31. Luo, Y.; Lü, Y.; Fu, B.; Zhang, Q.; Li, T.; Hu, W.; Comber, A. Half century change of interactions among ecosystem services driven by ecological restoration: Quantification and policy implications at a watershed scale in the Chinese Loess Plateau. Sci. Total Environ. 2019, 651, 2546-2557. [CrossRef]

32. Hou, Y.; Lü, Y.; Chen, W.; Fu, B. Temporal variation and spatial scale dependency of ecosystem service interactions: A case study on the central Loess Plateau of China. Landsc. Ecol. 2017, 32, 1201-1217. [CrossRef] 
33. Su, C.; Fu, B. Evolution of ecosystem services in the Chinese Loess Plateau under climatic and land use changes. Glob. Planet. Chang. 2013, 101, 119-128. [CrossRef]

34. Shang, X.; Li, X. Holocene vegetation characteristics of the southern Loess Plateau in the Weihe River valley in China. Rev. Palaeobot. Palynol. 2010, 160, 46-52. [CrossRef]

35. Wang, L.; Shao, M.; Wang, Q.; Gale, W.L. Historical changes in the environment of the Chinese Loess Plateau. Environ. Sci. Policy 2006, 9, 675-684. [CrossRef]

36. Cai, Q.G. Soil erosion and management on the Loess Plateau. J. Geogr. Sci. 2001, 11, 53-70. [CrossRef]

37. Fu, B.; Liu, Y.; Lü, Y.; He, C.; Zeng, Y.; Wu, B. Assessing the soil erosion control service of ecosystems change in the Loess Plateau of China. Ecol. Complex. 2011, 8, 284-293. [CrossRef]

38. Lü, Y.; Fu, B.; Feng, X.; Zeng, Y.; Liu, Y.; Chang, R.; Sun, G.; Wu, B. A policy-driven large scale ecological restoration: Quantifying ecosystem services changes in the Loess Plateau of China. PLoS ONE 2012, 7, e31782. [CrossRef]

39. Wu, B.; Qian, J.; Zeng, Y. Land Cover Atlas of the People's Republic of China (1:1,000,000); SinoMaps Press: Beijing, China, 2017.

40. Xie, G.; Zhang, C.; Zhen, L.; Zhang, L. Dynamic changes in the value of China's ecosystem services. Ecosyst. Serv. 2017, 26, 146-154. [CrossRef]

41. Plummer, M.L. Assessing benefit transfer for the valuation of ecosystem services. Front. Ecol. Environ. 2009, 7, 38-45. [CrossRef]

42. Richardson, L.; Loomis, J.; Kroeger, T.; Casey, F. The role of benefit transfer in ecosystem service valuation. Ecol. Econ. 2015, 115, 51-58. [CrossRef]

43. Xie, G.; Lu, C.; Leng, Y.; Zheng, D.; Li, S. Ecological assets valuation of the Tibetan Plateau. J. Nat. Resour. 2003, 18, 189-196. (In Chinese)

44. Jiang, W.; Lü, Y.; Liu, Y.; Gao, W. Ecosystem service value of the Qinghai-Tibet Plateau significantly increased during 25 years. Ecosyst. Serv. 2020, 44, 101146. [CrossRef]

45. Crespo-Cebada, E.; Díaz-Caro, C.; Robina-Ramírez, R.; Sánchez-Hernández, M.I. Is Biodiversity a Relevant Attribute for Assessing Natural Parks? Evidence from Cornalvo Natural Park in Spain. Forests 2020, 11, 410. [CrossRef]

46. Jenkins, C.N.; Joppa, L. Expansion of the global terrestrial protected area system. Biol. Conserv. 2009, 142, 2166-2174. [CrossRef]

47. Ren, Y.; Lü, Y.; Fu, B.; Comber, A.; Li, T.; Hu, J. Driving Factors of Land Change in China's Loess Plateau: Quantification Using Geographically Weighted Regression and Management Implications. Remote Sens. 2020, 12, 453. [CrossRef]

48. Du, X.; Zhao, X.; Liang, S.; Zhao, J.; Xu, P.; Wu, D. Quantitatively Assessing and Attributing Land Use and Land Cover Changes on China's Loess Plateau. Remote Sens. 2020, 12, 353. [CrossRef]

49. Foody, G.M. Valuing map validation: The need for rigorous land cover map accuracy assessment in economic valuations of ecosystem services. Ecol. Econ. 2015, 111, 23-28. [CrossRef]

50. Song, X.-P. Global Estimates of Ecosystem Service Value and Change: Taking into Account Uncertainties in Satellite-based Land Cover Data. Ecol. Econ. 2018, 143, 227-235. [CrossRef]

51. Yang, H.; Li, S.; Chen, J.; Zhang, X.; Xu, S. The Standardization and Harmonization of Land Cover Classification Systems towards Harmonized Datasets: A Review. Int. J. Geo-Inf. 2017, 6, 154. [CrossRef]

52. Song, P.; Kim, G.; Mayer, A.; He, R.; Tian, G. Assessing the Ecosystem Services of Various Types of Urban Green Spaces Based on i-Tree Eco. Sustainability 2020, 12, 1630. [CrossRef]

53. Xie, Q.; Yue, Y.; Sun, Q.; Chen, S.; Lee, S.; Kim, S.W. Assessment of Ecosystem Service Values of Urban Parks in Improving Air Quality: A Case Study of Wuhan, China. Sustainability 2019, 11, 6519. [CrossRef]

(C) 2020 by the authors. Licensee MDPI, Basel, Switzerland. This article is an open access article distributed under the terms and conditions of the Creative Commons Attribution (CC BY) license (http://creativecommons.org/licenses/by/4.0/). 